\title{
Economies of scale and scope in Australian higher education
}

\author{
Andrew C. Worthington · Helen Higgs
}

\begin{abstract}
This paper estimates economies of scale and scope for 36 Australian universities using a multiple-input, multiple-output cost function over the period 1998 to 2006. The three inputs included in the analysis are full-time equivalent academic and non-academic staff and physical capital. The five outputs are undergraduate, postgraduate and $\mathrm{PhD}$ completions, national competitive and industry grants, and publications. The findings indicate that ray economies of scale hold up to about 120 percent of current mean output though productspecific economies of scale hold only for undergraduate teaching. Global economies of scope prevail in the sector, increasing with the level of mean output, while product-specific economies of scope arise for all outputs except publications. A cost efficiency index constructed using the sector benchmark indicates that the universities of Ballarat, Southern Cross and Flinders have a high level of cost efficiency, while New South Wales, Royal Melbourne Institute of Technology and James Cook are cost inefficient.
\end{abstract}

Keywords Economies of scale $\cdot$ Economies of scope $\cdot$ Substitutes and complements in production · Cost efficiency

\section{Introduction}

It is patent that the Australian higher education sector has undergone substantial structural change during the last three decades. At the beginning of the 1980s, Australia had more than 80 higher education institutions operating in a dual system with research and teaching-focused universities funded on a different basis from teaching-focused institutes of technology and colleges of advanced education. With few exceptions, these institutions were comparatively small (an average size of less than 8,000 full-time equivalent students) with most operating within a comparatively narrow range of disciplines and focused on particular teaching, research, and research training roles.

However, the Dawkins reforms of the late 1980s brought the introduction of a unified national system accompanied by a far-reaching programme of restructuring that saw

A.C. Worthington $(\triangle) \cdot H$. Higgs

Griffith Business School, Griffith University,

Nathan, Queensland 4111, Australia

e-mail: aworthington@griffith.edu.au 
Australia's 18 universities and 60 colleges combine into just 38 universities, motivated partly by the argument that small institutions have unacceptably higher costs and tertiary institutions should have a broad educational profile. A partial underlying motivation was that if large and diverse institutions have lower costs, it is because economies of scale (average costs decline with output) and scope (costs are higher for specialist providers) arise in higher education. Since then, the move to a mass education system, changes in teaching and research funding and performance frameworks, and the expansion and development of Australia as a key provider of international education services, has seen further growth in size, with Australian universities growing to average 14,000 students in 1998 and more than 18,000 in 2006.

However, since the widespread program of mergers between 1987 and 1991, relatively little consolidation has taken place in the Australian higher education sector. Nevertheless, there are now signs that market and non-market revenue and cost pressures, and the desired policy outcomes of increasing the quality and diversity of Australian higher education, especially internationally, will focus attention on further possibilities for structural change with a new round of alliances, mergers, and restructurings. In evidence of these pressures, the Review of Australian Higher Education (2008, p. 147) pointed out several problems facing Australia's universities, starting with the fact that over the period 1995-2005, total national expenditure on tertiary institutions in Australia grew more slowly (34 per cent) than GDP (42 per cent) and significantly less than the OECD average (58 per cent). The clear inference is that Australian universities are substantially under-resourced.

Just as problematically, the increase in expenditure on tertiary education in Australia during this time was mainly due to increased private expenditure, primarily through student contributions and tuition fees. While the Review of Australian Higher Education (2008, p. 171) observed that these new funding sources had bestowed increased operational autonomy on universities, it also increased their exposure to financial risk, with 20 per cent of Australia's public universities having operating margins of less than 4 per cent in 2007, with another 15 per cent operating in deficit. Finally, the Review of Australian Higher Education (2008) suggested that Australia was losing ground on a range of indicators of the quality and performance of its tertiary education system, with universities struggling to do more with less. There are already signs these factors are having an effect on the structure of the sector. For example, in 2005 Edith Cowen University independently joined (ultimately fruitless) merger negotiations between Western Australia's Murdoch and Curtin universities. Likewise, in July 2008, the University of Canberra and Charles Sturt University confirmed they were exploring 
the establishment of a 'system university' along US lines following a similar May 2008 alliance between the Australian National University and the University of South Australia (Healy 2008).

Nevertheless, such pressures have been in place for some time. For instance, in 2007 the then Federal Minister for Education, Science and Training is recorded as stating that “...tweaking the priorities of the \$46.8 million Collaboration and Structural Reform Fund [would] reward proposals for university mergers and campus closures” and that Australia had room for perhaps only a dozen fully comprehensive, generic universities (Armitage 2007). Concern with the number of individual campuses has also been longstanding, with more than half of the more than 150 campuses in Australia having less than a thousand full-time equivalent students (Moodie 1999). However, this position is by no means universal, with Universities Australia (2008), the peak industry lobby group representing Australia's 39 universities, in its submission to the Review of Australian Higher Education (2008) contesting that Australia had a relatively low number of universities (per million of population) compared with key international competitors (including Canada, the UK and the US). Universities Australia (2008, p. 30) also recommended “...that instead of deliberately seeking to promote amalgamations or other radical structural measures, government policy settings should facilitate a focus on individual universities' unique areas of strength and on leaving institutions free to pursue greater networking or linkages”.

Both of these positions rely heavily on the contested premise that large universities are best able to exploit the competitive realities of global higher education and that the excessive diversification of Australian universities across teaching, research, and research training is associated with substantial costs at both the university and sector level. Given the pervasive belief among some policymakers and decision makers that larger, more specialised universities are more cost effective, it is now appropriate to review the available evidence on economies of scale and scope in Australian higher education. Astonishingly, little contemporary evidence exists. Throsby (1986) considered cost data for Australian universities and found that average costs fall quite steeply first, reaching a minimum level at around 13,000 full-time equivalent students, before slowly increasing. Lloyd et al. (1993) likewise concluded based on data from the late 1980s that large institutions in Australia do not fully exhaust economies of scale, and that these appear to offer greater potential gains than any economies of scope. 
Using a nonparametric approach, Abbot and Doucouliagos (2003) calculated relative measures of technical and scale efficiency of Australian universities for 1995 and concluded that while there was room for improvement, universities were operating at a fairly high level of efficiency relative to each other. These findings are comparable to an earlier study by Akviran (2001), also using data from 1995. Overall, these studies tend to support the existence of economies of scale, as depicted in Figure 1. As shown, plotting average costs per student completion in Australian universities provides at least some evidence of a U-shaped long-run average cost curve.

\section{$<$ FIGURE 1 HERE $>$}

Accordingly, the purpose of this paper is to assess the economies of scale and scope in Australian universities. While not the only study to examine efficiency and/or productivity in Australian universities (Throsby 1986; Lloyd et al. 1993; Madden et al. 1997; Akviran 2001; Abbott and Doucouliagos 2003; Carrington et al. 2005; Worthington and Lee 2008) it is the only one to focus exclusively on scale and scope economies at a university-level using recent panel data. This will throw useful light on the possibility of universities attaining efficiencies through structural change. The paper is divided into four main sections. The second section briefly discusses the concepts and sources of economies of scale and scope as they apply to higher education. The third section deals with the specification of higher education inputs, outputs and costs. The fourth section focuses on the cost function specification used to estimate the economies of scale and scope and the fifth section presents the results. The paper ends with some concluding remarks.

\section{Economies of scale and scope in higher education}

It is generally considered that the behavioural assumption of profit maximisation does not well fit universities operating in quasi-markets (markets where the government is a principal funder but not provider of services, and retains varying degrees of control on the number and size of institutions as well as the inputs and outputs employed in the production process). However, cost minimisation is readily applicable to nearly all market and non-market contexts desirous of efficiency and effectiveness in resource usage and output provision.

In contrast to the short run when at least some resource inputs (mostly capital) are assumed fixed, in the long run all resource inputs are variable. A university (as the firm) can, for example, alter its usage of plant and equipment, change management personnel, build new 
capacity through buildings and facilities, close down obsolete facilities or redundant campuses, update its use of information and other technology, or in any other way modify its production processes and use of resources over time. These discussions are important because while the university has many conceivable options as to equipment, technology, and the capital-labour mix in the long run, once a commitment is made its situation reverts to the short run, where many of these decisions are again fixed.

One possible long-run cost objective for a university is to be in a position to produce the desired output (or outputs) at the lowest possible cost (or cost minimisation). Among other things, this means adjusting its scale of production to the most appropriate size. Sometimes dividing the production process into smaller production units can result in economies, as evidenced by the division of universities into smaller administrative units like campuses, faculties, schools and departments. On other occasions, enlarging the scale of production can achieve lower unit costs. This can proceed over time through a continuum ranging from internal growth, through to strategic alliances, understandings, and agreements, to formal merger and amalgamation. Through this process, universities overcome indivisibilities in factor inputs and the spreading of fixed costs, avoid the costs of inventory stock outs, and gain access to economies in the fixed costs of production including purchasing, marketing and administration (including human resources and information technology).

The production process for a specific output is then said to exhibit economies of scale over a range of output when average cost $(A C)$ (i.e. cost per unit of output) declines over that range (where $A C=T C / Q)$. For long-run average cost $(L R A C)$ to decline, the marginal cost $(M C)$ (i.e. the cost of the last unit produced) must be less than overall average costs (where $M C=\Delta T C / \Delta Q$ ). If average cost is increasing, then marginal cost must exceed average cost and production exhibits diseconomies of scale. Generally, diseconomies of scale arise from the increase of input prices, the reduction of incentives and the growth of bureaucracy, and an increasing lack of specialised resources.

Average costs are typically U-shaped in cost-output space, so that the smallest and largest universities have equally high costs relative to medium-sized universities. That is, on either side of the minimum efficient scale (MES) of production, costs are rising so output less than or more than the MES is inefficient from a cost perspective. In practice, there is much variation. One possibility is that economies of scale are negligible and diseconomies dominate at relatively low levels of output. Elsewhere, economies of scale may be extremely important and decline continuously over a wide range until output diseconomies are experienced. This 
results in cost efficient outputs for output levels equal to and exceeding the MES. In yet other contexts, the LRAC may be virtually horizontal over a wide range of output: economies of scale are quickly exhausted though diseconomies are not encountered until very large levels of output are produced. These L-shaped cost curves are indicative that small, medium, and largesized universities could operate with an approximately equal level of cost efficiency beyond the point of MES where average costs are either flat or only slightly increasing.

The presence of economies (diseconomies) of scale rests on the functional relationship between the costs of production and the rate of output per period. In other words, costs = $f$ (output). However, the rate of output is, in turn, a function of the rate of usage of the resource inputs: that is, output $=f$ (inputs). Since the production function displays the relationship between input and output flows, once the prices of the inputs (or factor prices) are known, the costs of a specific quantity of output can be calculated. Consequently, the level and behaviour of costs as a university's rate of output changes (as evidenced by the LRAC) depends on two important factors: (i) the character of the underlying production function and (ii) the prices the firm must pay for its resource inputs. Generally, the first factor determines the shape of the cost function while the second determines the level of costs.

Consider now a university using $L$ units of labour (say, academic and non-academic labour) in combination with $K$ units of capital (both financial and physical) to obtain an output of $Q$ units such that $L+K \rightarrow Q$. Now assume that the amounts of labour and capital are increased by some arbitrary proportion $a$ with the expected proportional increase in output given by $b$ such that $a L+a K \rightarrow b Q$. When the change in output is more than proportional to the change in input $(b>a)$, increasing returns to scale are found. For example if the inputs of labour and capital increase by $20 \%$, output rises by $30 \%$. Alternatively, when the change is less than proportional to the change in inputs $(b<a)$, the firm experiences decreasing returns to scale. An example here would be the labour and capital inputs increase by $20 \%$ but outputs only rise by $10 \%$. Finally, where the change in output is proportional to the change in inputs $(b=a)$ constant returns to scale are present. In this case, increasing inputs by $20 \%$ would also result in output increasing by $20 \%$.

It is often tempting to use the terms economies (diseconomies) of scale (a cost concept) and increasing (decreasing) returns to scale (a production concept) interchangeably. While strictly incorrect, to yield economies of scale the production function must have some region of increasing returns to scale, and to yield diseconomies of scale it must have a region where there are decreasing returns to scale. In fact, the levels of output where economies 
(diseconomies) of scale and increasing (decreasing) returns to scale occur will exactly correspond when the firm faces constant input prices as output expands. This is most likely to occur for a relatively small entity in a competitive industry where input demand by one firm is likely to be small relative to total market demand. In other cases, however, where the firm's demand for inputs is large relative to total industry demand, situations may arise where economies of scale occur at the same time that the firm experiences constant (or even decreasing) returns to scale.

Consider, for example, a university with constant returns to scale in a decreasing cost industry. If the inputs $(L, K)$ increase by a given proportion $(a)$, output $(Q)$ will expand by the same proportion $(b)$ such that $b=a$ (i.e. constant returns-to-scale). However, if input prices decline as $Q$ rises, it follows that the average costs of producing $a Q$ must be less than the average cost of producing $Q$, and long-run average costs must fall (i.e. economies of scale). Similar arguments show that production can even exhibit decreasing returns to scale and we can still attain economies of scale so long as the impact on average costs by the decline in factor prices sufficiently offsets the increased use of inputs and vice versa.

In the above discussion, a single output is considered. Once multiple product production arises, the presence or absence of complementarity between outputs in production in a firm becomes important. This diversity of products (goods or services) within a single firm (or university in this case), known as 'scope', may provide cost advantages in that a single university producing a given level of output for product may spend less than a combination of several specialised universities. That is, economies of scope arise when it is cheaper in terms of total cost (TC) to produce some level $Q$ of product $A$ in conjunction with some level of product $B$, rather than each separately, $T C\left(Q_{A}, Q_{B}\right)<T C\left(Q_{A}, 0\right)+T C\left(0, Q_{B}\right)$. Among firms, this process often manifests itself as leveraging core competences, competing on capabilities, mobilizing invisible assets, diversification into related products, and umbrella branding. In the case of production in higher education organisations, the production process typically comprises multiproduct attributes because it produces multiple products (undergraduate and postgraduate teaching, research, research training, and stakeholder service) through the sharing and joint utilisation of inputs including academic and support staff, equipment, buildings, and so on.

Unfortunately, there a number of empirical difficulties associated with measuring cost economies in universities. First, the measures of outputs, including teaching, research, and research training, may vary in quality across universities. Fortunately, minimum standards 
often apply, but a strong correlation between university sizes and/or profile and quality may distort the results. Second, in quasi-markets unconstrained decisions by universities do not generate the observations used for analysis. Government policy and the allocation of funding, however well intentioned, still control the mix and level of university outputs, and these do not necessarily correspond to efficient outcomes. Finally, analysis assumes that universities are at some equilibrium point along their respective long-run cost functions. Universities, in fact, may be at different stages of growth and development and the absence of, say, evidence of diseconomies of scale may simply be because no universities in the sector are currently large enough for these diseconomies to apply, not that they do not exist.

\section{Specification of outputs, inputs and costs}

The data consist of annual observations of 36 Australian universities over the period 1998 to 2006. This is the longest and most recent period where the Commonwealth Department of Education, Science, and Training (DEST), now Department of Education, Employment and Workplace Relations (DEEWR), collected consistent data on university inputs, outputs and costs. The sample omits two universities, Sunshine Coast and Notre Dame Australia, as both are relatively small, and only began operation in 2000. The Australian National University is included, even though it had non-separable research funding associated with the Institute of Advanced Studies up to 1999: the data for the Australian National University accordingly only covers the period since 2000. The Australian Bureau of Statistics' consumer price index (education) is used to convert all monetary variables from nominal to real values $(2000=$ 100).

The inputs and outputs employed follow a production approach to modelling university behaviour; that is, universities combine labour and non-labour factors of production and produce outputs in the form of teaching, research, and research training. Six categories of output are employed. These are the number of undergraduate, postgraduate, and $\mathrm{PhD}$ completions, the value of national competitive and industry grants (in \$ thousands), and publications (in points). Note that student completions include degrees and other undergraduate qualifications while publications include (points awarded in brackets) books (5 points), book chapters (excluding textbooks) (1 point), refereed journal articles (1 point) and refereed conference proceedings (1 point) [see DEST (2006) for the eligibility criteria].

Unmistakably, the numbers of undergraduate and postgraduate awards are an obvious measure of output for any university. Similarly, research is also an important output, signified 
by ongoing government research funding being at the time distributed by a performance-based formula (weighting in brackets) comprising research income (60\%), publications (10\%) and doctoral students (30\%). Nevertheless, there are three obvious limitations with the selected output specification. First, using research income as a proxy for output is problematic in that it is arguably an input into the research process, not an output of the process. This could potentially involve misspecification in that the output affects the level of inputs. However, the fact remains that in Australia the government and other university stakeholders regard research income as a key indicator of university performance. Moreover, Flegg et al. (2004, p. 234) argue “...research income is likely to reflect the perceived quality, as well as quantity, of research output and it should provide a more up-to-date picture of such output than, for example, publications or citations, for which there is bound to be a considerable time lag”.

Second, there is no direct allowance for quality. Nevertheless, putting aside the lack of alternative measures, this is entirely consistent with current policy in the sector. For example, Commonwealth funding for students by discipline is identical across universities, a dollar of competitive research income is treated the same regardless of its source, and among the publications recognised as research outputs, there is currently no attempt to distinguish between high and low-quality outcomes. This was already likely to change with the previous Liberal-National government's Research Quality Framework (RQF) and now with the current Labor government's stated objective of promoting research quality and evaluation through the Excellence in Research for Australia (ERA) initiative.

Finally, there is no recognition of the non-teaching and non-research outputs that universities can provide. These include informed commentary by academics in the media and at public forums and inquiries, recreational services like sporting activities and cultural events, additional services for indigenous, rural, disabled, and other disadvantaged students and engagement with business and community groups. In the absence of any specific measurement, this analysis assumes such 'unmeasured' outputs increase in proportion to the measured outputs.

The major costs in university teaching, research and research training are the salaries of academic and non-academic staff. Unfortunately, the data do not allow the finer separation of academic staff into teaching-only, teaching and research, or research-only staff, nor is it possible to separate non-academic staff into teaching or research-related support services. Other inputs comprise non-labour expenditure, and these typically include the physical support of academic activities and research, libraries, other academic support services, student 
services, public services, buildings and grounds and administration and other general institution services). In the past, a reasonable assumption would be that the prices of all university inputs held constant across the sector, given centralised wage determination, the absence of enterprise bargaining agreements, and so on. Increasingly, however, large disparities have opened between universities in the prices of their inputs, operating as they do in an increasingly competitive market for academic labour (especially that tied closely to key research outcomes). One benefit of allowing prices to vary across universities is that it more accurately reflects differences in the relative prices of inputs that may arise among universities operating in different environments (including capital city vs. regional universities, and universities in the various states).

Accordingly, the input price of academic (non-academic labour) for each university is determined by dividing the expenditure on academic (non-academic) salaries by the number of full-time equivalent academic (non-academic) staff. The price of capital (non-labour input) is proxied by dividing non-labour expenditures by the stock of physical capital. Unfortunately, universities do not provide this information to DEST and so a proxy is that university capital corresponds to the full-time undergraduate and postgraduate student load. The total costs of each university each year are the sum of all labour and non-labour expenditures.

Table 1 presents a summary of descriptive statistics for annual costs, input prices, and outputs for the 36 Australian universities from 1998 to 2006 (with the exception of the Australian National University (ANU), which covers the period 2000 to 2006). Sample means, median, maximums, minimums and standard deviations are reported. Between 1998 and 2006, average annual total costs range from $\$ 88.1$ million (Ballarat) to $\$ 783.3$ million (Melbourne) with a sector average of $\$ 301.4$ million. The five highest cost universities comprise members of the Go8: namely, Melbourne (\$783.3 million), Sydney (\$752.3 million), Monash (\$707.2 million), Queensland (\$670.5 million), and New South Wales (\$663.5 million). The six lowest cost universities are Ballarat (\$88.1 million), Charles Darwin (\$88.5 million), Southern Cross (\$88.8 million), Australian Catholic (\$99.1 million), and Canberra (\$108.5 million).

\section{$<$ TABLE 1 HERE $>$}

In terms of inputs prices, the averages (in thousands) across the sector are $\$ 113.2$ thousand for academic labour, \$72.2 thousand for non-academic labour and \$7.4 thousand for capital (the prices for labour are per equivalent full-time staff member while the capital 
measure is per equivalent full-time student). The lowest priced academic labour is at Southern Queensland (\$87.1 thousand), New England (\$94.8 thousand) and Charles Sturt (\$95.7 thousand) while the highest priced academic labour is Swinburne (\$161.8 thousand), Charles Darwin (\$169.4 thousand) and Ballarat (\$175.3 thousand). The lowest priced non-academic labour is at Southern Queensland (\$57.3 thousand), New England (\$59.6 thousand) and Edith Cowan (\$60.4 thousand) while the highest priced is at Victoria University of Technology (\$86.5 thousand), Swinburne (\$115.5 thousand) and Charles Darwin (\$188.7 thousand). Finally, the least cost capital is at Australian Catholic ( $\$ 3.7$ thousand), Charles Sturt (\$4.1 thousand) and Southern Queensland ( $\$ 4.3$ thousand) while the most costly capital is at Western Australia (\$11.8 thousand), Charles Darwin (\$12.9 thousand) and ANU (\$25.1 thousand).

The universities with the highest average undergraduate completions are Monash $(8,454)$, Melbourne $(7,242)$, Sydney $(6,611)$, Queensland University of Technology $(6,006)$, Western Sydney $(5,812)$ and the lowest are Charles Darwin (517), Ballarat $(1,065)$, James Cook $(1,600)$, Southern Cross $(1,656)$ and Canberra $(1,737)$. Across the sector, undergraduate completions average 3,573 students annually. For postgraduate completions, the sector average is 1,818 students with New South Wales (3,964), Monash $(3,893)$, University of Technology Sydney $(3,775)$, Melbourne $(3,694)$, Sydney $(3,127)$, graduating more and Charles Darwin (309), James Cook (467), Tasmania (470), Murdoch (636), and Southern Cross (652) graduating fewer postgraduate students.

The final three outputs broadly correspond to university outputs in research and research training. The highest number of doctoral completions is at Melbourne (444), Sydney (411), Queensland (380), New South Wales (338), Monash (309) and the lowest are at University of Ballarat (12), Australian Catholic (16), Charles Darwin (17), Central Queensland (18) and Canberra (19). The sector average is 124 doctoral completions. For grants, Melbourne (\$137.2 millions), Sydney (\$125.7 millions), and Queensland (\$106.3 millions) rank highest and the lowest is at Australian Catholic (\$1.3 millions), Ballarat (\$1.8 millions), and Central Queensland (\$2.0 millions). The overall annual average dollar value of national competitive and industry grants for period is $\$ 28.2$ million. Finally, the average publication points per university per year is 937 with the highest average number of publications at Sydney (2,762), Queensland (2,712), and Melbourne (2,568), and the lowest average at Charles Darwin (123), Southern Cross (165) and Australian Catholic (186). 


\section{Model specification}

A cost function is employed to estimates the economies of scale and scope in Australian higher education. The basic assumption is that universities seek to minimise their costs at some chosen level of output subject to the relative prices of their factor inputs. This approach has been used in a relatively large number of studies of higher education costs in Australia and elsewhere [Cohn et al. (1989), de Groot et al. (1991), Lloyd et al. (1993), Lewis and Dundar (1995), Hashimoto and Cohn (1997), Koshal and Koshal (1995; 1999; 2000), Izadi et al. (2002), O’Connell and Perkins (2003), Laband and Lentz (2003), Sav (2004), Stevens (2005), McMilland and Chan (2006), Lenton (2007) and Johnes et al. (2008)]. Alternative approaches to the study of university costs include cost frontiers [see Worthington (2001) and Johnes (2006) for useful surveys of frontier efficiency measurement in education].

A quadratic cost function is used for this purpose. This has the advantage of a flexible specification applicable to multifactor production. The cost function is also an appropriate form to take account of the linear, quadratic and cross-product terms found with more than one factor input. A cost function that allows the economies of scale to vary with different levels of input prices and output is specified as:

$$
C=\beta_{0}+\sum_{i=1}^{8} \beta_{i} y_{i}+1 / 2 \sum_{i=1}^{8} \delta_{i}\left(y_{i}\right)^{2}+\sum_{\substack{i, j=1 \\ i \neq j}}^{8} \gamma_{i j} y_{i} y_{j}+\varepsilon_{i}
$$

where $\beta_{0}$ is the fixed cost term, $\beta_{i}(i=1,2, \ldots, 8)$ are the slope coefficients of the linear term, $\delta_{i}(i=1,2, \ldots, 8)$ are the slope coefficients of the quadratic terms, $\gamma_{i j}(i=1,2, \ldots, 8, j=1,2, \ldots$, 8 and $i \neq j$ ) are the slope coefficients of the cross-product terms, $C$ is the of the total operating costs of each university (in $\$$ millions) and $y_{1}$ to $y_{8}$ represent the prices of the academic and non-academic labour inputs and capital inputs (in \$ thousands), undergraduate, postgraduate and $\mathrm{PhD}$ completions (in number), competitive grants (in \$ thousands) and publications (in points).

Using Shephard's Lemma, the factor demands can be obtained by differentiating the cost function in equation (1) with respect to the input prices.

$$
\frac{\partial C}{\partial P_{i}}=\frac{\partial C}{\partial P_{i}} \frac{P_{i}}{C}=\frac{X_{i} P_{i}}{C}=C S\left(P_{i}\right)
$$

or 


$$
C S\left(P_{i}\right)=\frac{\partial C}{\partial P_{i}}=\beta_{i}+\delta_{i} y_{i}+\sum_{\substack{i, j=1 \\ i \neq j}}^{8} \gamma_{i j} y_{j}
$$

where $C S\left(P_{i}\right)$ is the ith factor cost share and $X_{i}$ is the quantity of the ith input and $P_{i}$ is the price of the ith input (academic and non-academic labour and capital).

It is possible to improve the efficiency of the parameter estimates by estimating equation (1) with the cost share equations (3). The cost share for the three input prices must sum to one and this restriction produces singularity in the covariance of equation (3). The system of equations is estimated jointly by omitting one of the cost share equations in (3) together with equation (1) using a seemingly unrelated regression model imposing symmetry and the coefficients of the three input price coefficients to sum to one. The price of capital is the omitted input price.

The cost function in (1) allows the estimation of the economies of scale and scope. Following Baumol et al. (1982), Cohn and Geske (1990), Lewis and Dundar (1995) Hashimoto and Cohn (1997), Koshal and Koshal (1999; 2000), Sav (2004) and Johnes et al. (2008), these are defined as ray economies of scale, product-specific economies of scale and product-specific economies of scope. Under ray economies of scale, the composition of each university's output is assumed to remain fixed while the aggregate size of output varies. This provides a measure of scale analogous to the single output case where ray economies (diseconomies) of scale exist if the measure is greater (less) than unity. Product specific economies of scale, however, allow one output to vary, while all other outputs are held constant. Product-specific economies (diseconomies) of scale then exist if the measure is greater (less) than unity. Finally, product-specific economies of scope measure whether the cost of producing the outputs jointly is less than the costs of producing them separately. A value greater than or equal to zero thus indicates that cost advantages accrue through the joint production of outputs.

The method for calculating these measures is as follows. First, the average incremental cost, $\left.\operatorname{AIC}\left(y_{i}\right)\right)$ for producing output $y_{i}$ is defined as:

$$
\operatorname{AIC}\left(y_{i}\right)=\frac{C(y)-C\left(y_{N-i}\right)}{y_{i}} \quad i=4,5, \ldots 8
$$

where $C(y)$ is the total cost of producing the five outputs and $C\left(y_{N-1}\right)$ is the total cost of producing zero units of the ith output. In the case of a single product, the economies of scale 
are measured by the average incremental cost divided by the marginal cost. The productspecific economies of scale for $y_{i}, E\left(y_{i}\right)$ are specified as:

$$
E\left(y_{i}\right)=\frac{\operatorname{AIC}\left(y_{i}\right)}{M C\left(y_{i}\right)}
$$

where $\left.M C\left(y_{i}\right)=\partial C / \partial y_{i}\right)$ is the marginal cost of producing $y_{i}$ units of output. Ray economies of scale exist when the quantities of the product are increased proportionately and are presented as:

$$
E(R A Y)=\frac{C(y)}{\sum_{i=4}^{8} y_{i} \times M C\left(y_{i}\right)}
$$

If $E\left(y_{i}\right)$ or $E(R A Y)$ is greater than one (less) than one then economies of scale (diseconomies of scale) exists for output $y_{i}$.

Second, economies of scope can be divided into global economies of scope (GES) and product-specific economies of scope (PES) and these are defined as:

$$
G E S\left(y_{i}\right)=\frac{\sum_{i=4}^{8} C\left(y_{i}\right)-C(y)}{C(y)}
$$

The product-specific economies of scope are calculated as:

$$
\operatorname{PES}\left(y_{i}\right)=\frac{C\left(y_{i}\right)+C\left(y_{N-i}\right)-C(y)}{C(y)}
$$

\section{Empirical results}

The estimated coefficients, standard errors and $p$-values of the cost function are presented in Table 2. It is clear that the model will inevitably have multicollinearity as the explanatory variables contain a linear combination of input prices and outputs together with squared and cross-product terms. A simple test using the pairwise correlation between the explanatory variables (not shown) indicates the presence of collinearity with 17 percent of the pairs coefficients exceeding the rule of thumb factor of 0.8 . Accordingly, it is generally difficult to interpret the estimated slopes of quadratic cost functions. The $\mathrm{R}^{2}$ for the cost function in equation (1) is 0.9862 and this is comparable to similar measures of predictability in higher education elsewhere. The null hypotheses of no input price or output effects are jointly tested in addition with various tests of no linear, quadratic and output cross-product effects with the 
Chi-squared test statistics in Table 2. All hypotheses are rejected at the one percent level of significance, thus suggesting that jointly all groups of explanatory variables should be included in estimating the cost function for the thirty-six Australian universities.

\section{$<$ TABLE 2 HERE $>$}

The estimated quadratic cost function in Table 2 is used to estimate the marginal costs (MC) and average incremental costs (AIC) for each of the five university outputs (undergraduate completions, postgraduate completions, $\mathrm{PhD}$ completions, national competitive and industry grants and publications) for levels of mean output running from $50 \%$ to $300 \%$ (i.e. $100 \%$ is the mean output) in Table 3 . The mean values are 3572.60 undergraduate completions, 1818.02 postgraduate completions and 123.54 $\mathrm{PhD}$ completions, \$28155.99 (thousand) in national competitive and industry grants and 936.61 publication points. As shown, the marginal cost of undergraduate completions declines over the various levels of output, falling from $\$ 49,962$ per completion at $50 \%$ of mean output the $\$ 39,772$ at $300 \%$ of output. However, the marginal costs of the remaining four outputs all increase as output increases from $50 \%$ to $300 \%$ of output, from just $\$ 4,711$ to $\$ 50,464$ per postgraduate completion, $\$ 129,839$ to $\$ 512,362$ per $\mathrm{PhD}$ completion, from $\$ 1.39$ to $\$ 4.12$ per dollar of national competitive and industry grants, and from $\$ 13,374$ to $\$ 78,549$ per publication point. As in Lewis and Dundar (1995), $\mathrm{PhD}$ completions are the most costly output at the margin for universities while undergraduate completions are the least costly.

\section{$<$ TABLE 3 HERE $>$}

However, while the marginal costs increase prohibitively at very high levels of output, the average costs are more stable. For example, at 200\% of mean output, while the average cost of an undergraduate completion is $\$ 47,924$ compared to the marginal cost of $\$ 43,848$, for postgraduate completions the average costs is just $\$ 9,795$ compared to a marginal cost of $\$ \$ 30,192$ and for $\mathrm{PhD}$ completions the average cost is $\$ 206,344$ and the marginal cost is $\$ 359,353$. With grants and publications the average (marginal) costs are \$1.44 (\$2.78) and $\$ 26,409$ (\$52,479), respectively. Of course, this is to be expected as changes in marginal costs take some time to be reflected in significant changes in average costs. An important point to note is that as the data available does not allow completions to be separated by discipline, the marginal and average costs are across all disciplines and we would expect substantially variation in costs across, say, the social, natural, mechanical and health sciences. 
The product-specific and ray economies of scale are presented in Table 4. As defined earlier, the point estimates represent the degrees of ray economies (diseconomies) of scale: if the point estimate is greater than unity, then ray economies of scale exist across the output set. As shown, ray economies (the proportional augmentation of output holding composition constant) exist from $50 \%$ to $100 \%$ of the mean output over the sample period. However, between $100 \%$ and $125 \%$ of mean output diseconomies arise and hold for all levels of mean output up to $300 \%$. This suggests that the sector as a whole is currently experiencing economies of scale and there is a clear incentive to expand the production of all outputs to exploit existing potential scale economies. However, diseconomies of scale will arise if output increases beyond $125 \%$ of the mean. The findings also suggest that expanding output for smaller universities (less than $100 \%$ of the sector mean) would increase efficiency in the production of teaching, research and research training, assuming, of course, that the quality levels of the outputs is held constant.

\section{$<$ TABLE 4 HERE $>$}

Table 4 also includes the product-specific economies of scale. Clearly, economies of scale for undergraduate completions are increasing for all tabled levels of output. However, postgraduate completions, $\mathrm{PhD}$ completions, national competitive and industry grants and publications there are diseconomies of scale at these levels of output and these appear relatively stable. This complements the work of Lewis and Dundar (1995) on Turkish universities who also found no evidence of scale economies in research output, and Koshal and Koshal (2000) who concluded declining economies of scale in research and research training in US liberal arts colleges. However, it is important to note that diseconomies of scale can coincide with increasing returns to scale because increases in factor prices have offset any physical gains. For instance, the growth of the Australian university sector has seen increases in the factor prices for specialized research and research training academic staff in a relatively noncompetitive industry and these may offset the benefits of scale.

As with most university systems, production in Australian higher education typically involves joint production as a teaching, research and research training outputs are produced jointly and it is not possible to divide the costs of production accurately into their separate uses. As shown in Table 4, the global economies of scope are positive and increasing for all levels of mean output. This indicates that there are economies of scope at the existing product combination and that these scope economies can be better exploited as scale increases. The 
pattern of positive and increasing economies of scope is repeated for all of the productspecific economies of scope with the exception of publications. These results suggest that material opportunities for the joint production of undergraduate and postgraduate teaching and research training arise at all levels of output, but the evidence supporting scope economies in research is more mixed with national competitive and industry grants benefiting from joint production, but publications having diseconomies of scope. Nevertheless, the diseconomies of scope for publications are declining at very high levels of mean output (+300\%) and may eventually become economies of scope; however, this would be at a higher level of output than any existing Australian university.

The final part of the analysis calculates a cost efficiency index for individual Australian universities over the sample period by comparing their predicted costs using the sector wide equation in Table 2 and their own combination of factor input prices and levels of outputs and their actual mean costs over the period. In this table, a cost efficiency value greater (less) than unity indicates that actual costs are higher (lower) than the theoretical costs. That is, the university is cost inefficient (efficient) in terms of the sector benchmark if the index value is less (greater) than unity. It is also important to note that cost efficiency includes both technical efficiency — the ability to maximize outputs relative to a given level of inputs, or equivalently, minimize inputs for a given level of output-and allocative efficiency---the ability to employ factor inputs in their optimal proportions given their respective prices. We leave the decomposition of cost efficiency into its technical and allocative components for future study.

As shown, there appears to be no clear connection between the measure of cost efficiency and membership of one of the university lobby groups that have arisen in recent years (Group of Eight, Innovative Research Universities Australia, Australian Technology Network, New Generation Universities and ungrouped universities). However, at least some of these universities have been the subject of recent publicity in terms of a deteriorating and/or challenging financial position. For example, Central Queensland, Queensland University of Technology, Griffith University and the University of Queensland are high-cost multi-campus universities based in Queensland that have grown substantially in recent years (the Queensland University of Technology closed its Carseldine campus in 2008). Similarly, La Trobe is using staff cuts to restore its operating surplus to 3 per cent of revenue in 2009 (Trounson 2008); Royal Melbourne Institute of Technology has been the subject of serious ongoing financial management problems, including budget blowouts and poor business 
planning; while James Cook recently expressed concern about meeting staff demands for pay and conditions in the next enterprise bargaining agreement.

\section{Concluding remarks}

This study examined economies of scale and scope in Australian universities over the period 1998 to 2006. The inputs included in the analysis are full-time equivalent academic and nonacademic staff and non-labour expenditure and the outputs are undergraduate, postgraduate and $\mathrm{PhD}$ completions, national competitive and industry grants and publications. Productspecific and ray economies of scale and product-specific and global economies of scope are calculated using estimates from a quadratic cost function. The main findings are as follows. First, there is evidence of ray economies of scale (assuming the composition of outputs remains unchanged) but only up to $100 \%$ of mean output. After this point, diseconomies of scale arise and so there is little incentive for universities to expand output far beyond current levels, at least in terms of ray economies of scale. However, there are continuous increases in product-specific economies of scale for undergraduate completions, from $50 \%$ to $300 \%$ of the mean output, and this suggests further increases in output in this area could be at lower average cost.

Second, in contrast the evidence for economies for scope is very strong, with global economies of scale at all levels of mean output. This indicates that universities benefit (in terms of cost) from the joint production of teaching, research, and research training outputs. However, while product-specific economies of scope hold for undergraduate, postgraduate and $\mathrm{PhD}$ completions and grants, there are diseconomies of scope when publications increase relative to the other outputs. This suggests there is a cost disadvantage associated with the production of publications in isolation from other university outputs.

In terms of future research, a key limitation of this analysis is that no direct allowance has been given to the quality of inputs and outputs. For example, if the quality of outputs increases substantially with output, the diseconomies found with the quantity only output of publications may convert to economies of scale. From a different perspective, it is also unlikely that the academic inputs across the sector are consistently of the same quality. Possible extensions to address the former would be to include the Academic Ranking of World Universities compiled by Shanghai Jiao Tong University (regretfully only available since 2003) for a university-wide measure of quality or the Graduate Careers Australia's annual Australian Graduate Survey for teaching outputs only. Clearly, the current emphasis of 
the new Commonwealth government on a research quality framework [similarly to past developments in the UK] is also a step in this direction, and may ultimately yield new information that will assist future researchers by enabling them to include both quantity and quality dimensions in their analyses.

\section{References}

Abbott, M., \& Doucouliagos, C. (2003). The efficiency of Australian universities: A data envelopment analysis. Economics of Education Review, 22, 89-97.

Allen, D.O. \& Flegg, A.T. (2007). Does expansion cause congestion? The case of the older British universities, 1994-2004. Education Economics, 15, 75-102

Armitage, C. (2007) Bishop plan to cut unis, The Australian 11 April.

Australian Government (2008). Review of Australian Higher Education Final Report. Available at www.deewr.gov.au/. Accessed April 2010.

Avkiran, N. K. (2001). Investigating technical and scale efficiencies of Australian universities through data envelopment analysis. Socio-Economic Planning Sciences, 35, 57-80.

Baumol, W. J., Panzar, J. C., \& Willig, R. D. (1982). Contestable markets and the theory of industry structure. New York: Harcourt Brace Jovanovich.

Carrington, R., Coelli, T., \& Rao, P. (2005). The performance of Australian universities: Conceptual issues and preliminary results. Economic Papers, 24, 145-163.

Cohn, E., \& Geske, T. G. (1990). The economics of education, 3rd Edition. Oxford: Pergamon Press.

Cohn, E., Rhine, S. L. W., \& Santos, M. C. (1989). Institutions of higher education as multi-product firms: Economies of scale and scope. The Review of Economics and Statistics, 71, 284-290.

de Groot, H., McMahon, W. W., \& Volkwein, J. F. (1991). The cost structure of American research universities. The Review of Economics and Statistics, 73, 424-431.

Department of Education, Science and Technology (2006) Higher education research data collection specifications for the collection of 2005 data. Available at http://www.dest.gov.au/. Accessed June 2006.

Dundar, H., \& Lewis, D. R. (1995). Departmental productivity in American universities: Economies of scale and scope. Economics of Education Review, 14, 119-144.

Flegg, A. T., Allen, D. O., Field, K. \& Thurlow, T. W. (2004) Measuring the efficiency of British universities: a multi-period data envelopment analysis, Education Economics, 12, 231-249.

Getz, M., Siegfried, J. J., \& Zhang, H. (1991). Estimating economies of scale in higher education. Economics Letters, 37, 203-208.

Hashimoto, K., \& Cohn, E. (1997). Economies of scale and scope in Japanese private universities. Education Economics, 5, 107-115.

Healy, G. (2008) No merger but unis debate systems, The Australian, July 16.

Izadi, H., Johnes, G., Oskrochi, R., \& Crouchley, R. (2002). Stochastic frontier estimation of a CES cost function: the case of higher education in Britain. Economics of Education Review, 21, 63-71.

Johnes, G. (1996). Multi-product cost functions and the funding of tuition in UK universities. Applied Economics Letters, 3, 557-561.

Johnes, G., Johnes, J., \& Thanassoulis, E. (2008). An analysis of costs in institutions of higher education in England. Studies in Higher Education, 33, 527-549.

Johnes, J. (2006). Data envelopment analysis and its application to the measurement of efficiency in higher education. Economics of Education Review, 25, 273-288.

Koshal, R. K., \& Koshal, M. (1995). Quality and economies of scale in higher education. Applied Economics, 27, 773-778.

Koshal, R. K., \& Koshal, M. (1999). Economies of scale and scope in higher education: a case of comprehensive universities. Economics of Education Review, 18, 269-277.

Koshal, R. K., \& Koshal, M. (2000). Do liberal arts colleges exhibit economies of scale and scope? Education Economics, 8, 209-220. 
Laband, D. N., \& Lentz, B. F. (2003). New estimates of economies of scale and scope in higher education. Southern Economic Journal, 70, 172-183.

Lenton, P. (2007) The cost structure of higher education colleges in England, Economics of Education Review, 27, 471-482

Lewis, D. R., \& Dundar, H. (1995). Economies of scale and scope in Turkish universities. Education Economics, 3, 133-157.

Lloyd, P. J., Morgan, M. H., \& Williams, R. A. (1993). Amalgamations of universities: are there economies of scale or scope? Applied Economies, 25, 1081-1012.

Madden, G. Savage, S. and Kemp, S. (1997) Measuring public sector efficiency: A study of economics departments in Australian universities, Education Economics, 5, 153-168.

McMillan, M. L., \& Chan, W. H. (2006). University efficiency: A comparison and consolidation of results from stochastic and non-stochastic methods. Education Economics, 14, 1-30.

Moodie, G. (1999) Too many campuses spoil the system, The Australian, December 8.

O'Connell, J. F., \& Perkins, G. M. (2003). The economics of private liberal arts colleges. Journal of Business, 76, 499-514.

Patterson, G. (2000). Findings on economies of scale in higher education: implications for strategies of merger and alliance. Tertiary Education and Management, 6, 259-269.

Sav, G. T. (2004). Higher education costs and scale and scope economies. Applied Economics, 36, 607-614.

Stevens, P. A. (2005). A stochastic frontier analysis of English and Welsh universities Education Economics, 13, 355-374.

Throsby, D. (1986) Cost functions for Australian universities, Australian Economic Papers, 25, 175-192.

Trounson, A. (2008) La Trobe to offer redundancies, The Australian, November 12.

Universities Australia (2008) Universities Australia Submission to the Review of Australian Higher Education. Available at http://www.universitiesaustralia.edu.au/. Accessed April 2010.

Worthington, A.C. (2001). An empirical survey of frontier efficiency measurement techniques in education. Education Economics, 9, 245-268.

Worthington, A.C., \& Lee, B.L. (2008) Efficiency, technology and productivity change in Australian universities, 1998-2003, Economics of Education Review, 27, 285-298. 
Figure 1 Average cost and student completions by university, 1998-2006

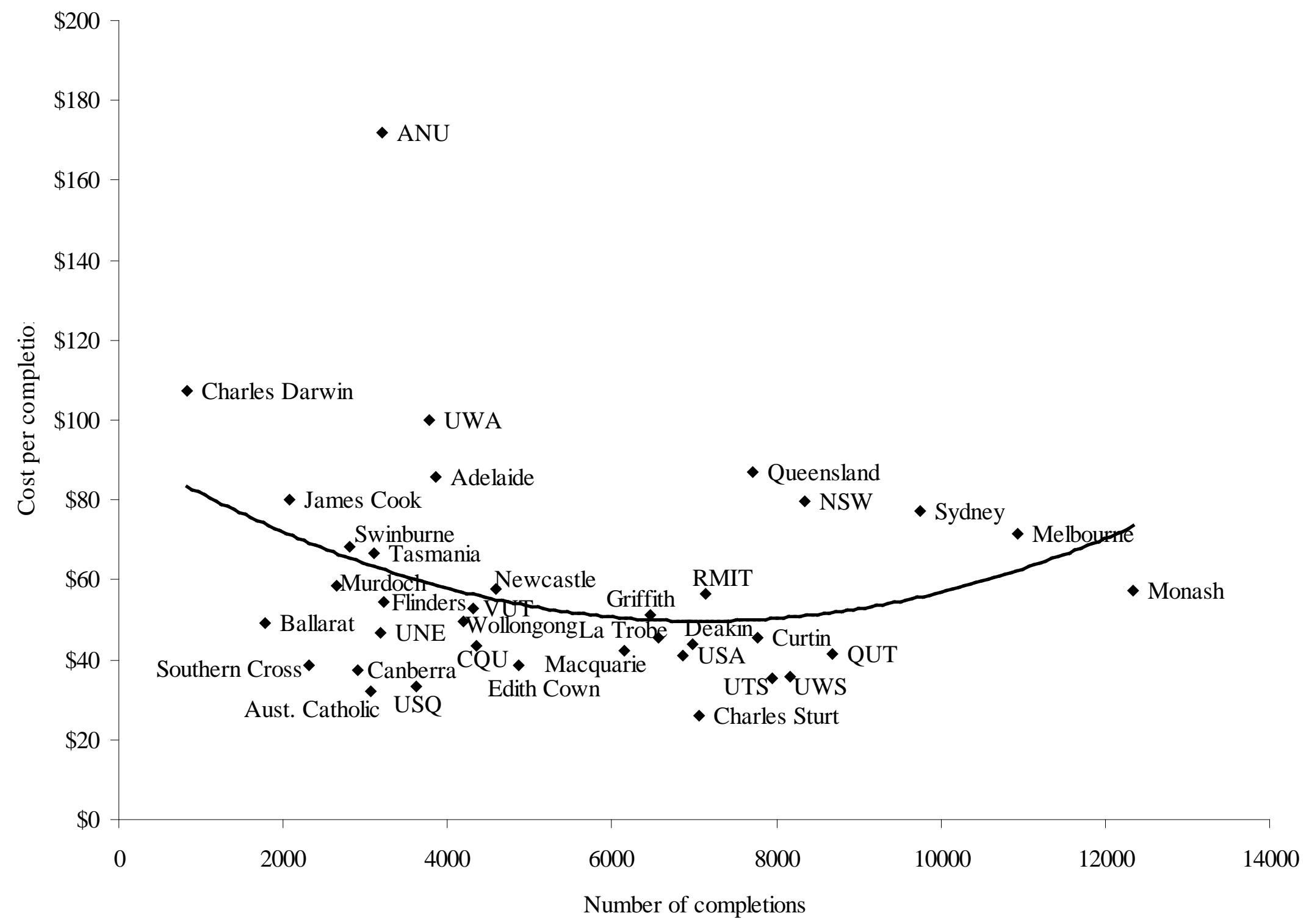


Table 1 Selected descriptive statistics of university costs, input prices and outputs, 1998-2006

\begin{tabular}{|c|c|c|c|c|c|c|c|c|c|c|}
\hline University & Statistic & $\begin{array}{l}\text { Total } \\
\text { costs }\end{array}$ & $\begin{array}{c}\text { Price of } \\
\text { academic } \\
\text { labour }\end{array}$ & $\begin{array}{c}\text { Price of non- } \\
\text { academic } \\
\text { labour }\end{array}$ & $\begin{array}{c}\text { Price of } \\
\text { capital }\end{array}$ & $\begin{array}{c}\text { Undergraduate } \\
\text { completions }\end{array}$ & $\begin{array}{l}\text { Postgraduate } \\
\text { completions }\end{array}$ & $\begin{array}{c}\mathrm{PhD} \\
\text { completions }\end{array}$ & $\begin{array}{c}\text { National } \\
\text { competitive } \\
\text { and industry } \\
\text { grants }\end{array}$ & Publications \\
\hline \multirow{5}{*}{ All universities } & Mean & 301.44 & 113.27 & 72.24 & 7.42 & 3572.60 & 1818.02 & 123.54 & 28155.99 & 936.61 \\
\hline & Median & 251.58 & 105.27 & 67.67 & 6.50 & 3042.00 & 1554.50 & 87.00 & 13014.94 & 646.70 \\
\hline & Maximum & 1095.68 & 350.30 & 181.46 & 26.96 & 10107.00 & 5634.00 & 553.00 & 210064.20 & 3877.98 \\
\hline & Minimum & 45.29 & 39.97 & 46.77 & 2.76 & 415.00 & 253.00 & 3.00 & 204.04 & 65.90 \\
\hline & Std. Dev. & 207.92 & 34.48 & 19.36 & 3.82 & 1928.75 & 1150.33 & 119.77 & 38785.51 & 850.90 \\
\hline \multirow{5}{*}{$\begin{array}{l}\text { Australian } \\
\text { Catholic } \\
\text { University }\end{array}$} & Mean & 99.12 & 112.33 & 62.87 & 3.66 & 1905.89 & 1161.22 & 15.78 & 1284.81 & 185.70 \\
\hline & Median & 93.55 & 108.55 & 64.74 & 3.88 & 1825.00 & 1123.00 & 10.00 & 1585.19 & 149.13 \\
\hline & Maximum & 130.18 & 179.42 & 74.16 & 4.46 & 2329.00 & 1552.00 & 41.00 & 1907.38 & 283.72 \\
\hline & Minimum & 74.07 & 87.05 & 50.95 & 2.76 & 1662.00 & 953.00 & 5.00 & 204.04 & 76.83 \\
\hline & Std. Dev. & 21.42 & 28.75 & 7.49 & 0.57 & 247.72 & 165.79 & 13.07 & 629.96 & 76.92 \\
\hline \multirow{5}{*}{$\begin{array}{l}\text { Australian } \\
\text { National } \\
\text { University }\end{array}$} & Mean & 551.05 & 128.09 & 75.38 & 25.07 & 1940.29 & 1262.57 & 246.00 & 68808.11 & 2351.07 \\
\hline & Median & 594.34 & 122.14 & 73.98 & 24.68 & 1923.00 & 1107.00 & 232.00 & 80589.20 & 2339.94 \\
\hline & Maximum & 686.46 & 220.43 & 89.93 & 26.96 & 2251.00 & 1828.00 & 300.00 & 96608.65 & 2904.47 \\
\hline & Minimum & 407.81 & 89.70 & 61.57 & 24.16 & 1622.00 & 725.00 & 217.00 & 35150.75 & 1835.27 \\
\hline & Std. Dev. & 114.06 & 43.67 & 11.41 & 1.03 & 287.48 & 496.42 & 30.13 & 25933.49 & 446.68 \\
\hline \multirow{5}{*}{$\begin{array}{l}\text { Central } \\
\text { Queensland } \\
\text { University }\end{array}$} & Mean & 189.06 & 98.07 & 62.95 & 7.82 & 2409.67 & 1948.67 & 18.44 & 2010.52 & 265.05 \\
\hline & Median & 209.28 & 97.13 & 62.76 & 8.22 & 2589.00 & 1964.00 & 19.00 & 2253.62 & 230.17 \\
\hline & Maximum & 270.52 & 117.69 & 73.53 & 9.42 & 3368.00 & 3703.00 & 35.00 & 2761.92 & 386.89 \\
\hline & Minimum & 107.83 & 84.46 & 53.71 & 5.88 & 1433.00 & 784.00 & 8.00 & 1313.19 & 172.39 \\
\hline & Std. Dev. & 60.25 & 12.60 & 7.54 & 1.34 & 687.29 & 965.73 & 7.84 & 522.56 & 84.70 \\
\hline \multirow{5}{*}{$\begin{array}{l}\text { Charles Darwin } \\
\text { University }\end{array}$} & Mean & 88.50 & 169.36 & 118.73 & 12.93 & 517.22 & 308.67 & 17.44 & 4299.27 & 122.91 \\
\hline & Median & 92.05 & 188.08 & 110.88 & 12.90 & 515.00 & 302.00 & 19.00 & 2597.97 & 105.11 \\
\hline & Maximum & 139.31 & 350.30 & 181.46 & 21.19 & 590.00 & 378.00 & 23.00 & 9503.19 & 199.64 \\
\hline & Minimum & 46.10 & 80.42 & 58.44 & 6.20 & 415.00 & 253.00 & 9.00 & 1396.54 & 69.51 \\
\hline & Std. Dev. & 39.01 & 89.90 & 51.72 & 6.20 & 53.66 & 43.44 & 4.56 & 3436.55 & 46.27 \\
\hline \multirow{5}{*}{$\begin{array}{l}\text { Charles Sturt } \\
\text { University }\end{array}$} & Mean & 185.24 & 95.70 & 64.25 & 4.06 & 4791.89 & 2275.78 & 25.89 & 3765.26 & 366.04 \\
\hline & Median & 173.87 & 90.72 & 59.84 & 3.83 & 4792.00 & 2217.00 & 25.00 & 3815.13 & 380.53 \\
\hline & Maximum & 239.03 & 121.98 & 78.92 & 4.87 & 5754.00 & 2986.00 & 42.00 & 6257.26 & 684.32 \\
\hline & Minimum & 142.05 & 73.45 & 54.40 & 3.53 & 3684.00 & 1551.00 & 15.00 & 2239.25 & 110.00 \\
\hline & Std. Dev. & 32.63 & 15.69 & 9.34 & 0.49 & 727.18 & 514.43 & 9.12 & 1366.17 & 199.18 \\
\hline
\end{tabular}




\begin{tabular}{|c|c|c|c|c|c|c|c|c|c|c|}
\hline University & Statistic & $\begin{array}{l}\text { Total } \\
\text { costs }\end{array}$ & $\begin{array}{c}\text { Price of } \\
\text { academic } \\
\text { labour }\end{array}$ & $\begin{array}{l}\text { Price of non- } \\
\text { academic } \\
\text { labour }\end{array}$ & $\begin{array}{l}\text { Price of } \\
\text { capital }\end{array}$ & $\begin{array}{l}\text { Undergraduate } \\
\text { completions }\end{array}$ & $\begin{array}{l}\text { Postgraduate } \\
\text { completions }\end{array}$ & $\begin{array}{c}\text { PhD } \\
\text { completions }\end{array}$ & $\begin{array}{c}\text { National } \\
\text { competitive } \\
\text { and industry } \\
\text { grants }\end{array}$ & Publications \\
\hline \multirow{5}{*}{$\begin{array}{l}\text { Curtin University } \\
\text { of Technology }\end{array}$} & Mean & 352.80 & 112.14 & 69.30 & 6.47 & 5807.67 & 1957.67 & 111.02 & 16244.83 & 757.68 \\
\hline & Median & 344.79 & 108.36 & 70.66 & 6.48 & 5852.00 & 2141.00 & 91.00 & 15188.76 & 654.58 \\
\hline & Maximum & 434.08 & 132.64 & 81.85 & 6.99 & 6901.00 & 2743.00 & 159.17 & 25526.91 & 1081.01 \\
\hline & Minimum & 266.31 & 90.47 & 54.37 & 5.88 & 4676.00 & 1216.00 & 69.00 & 9955.82 & 590.66 \\
\hline & Std. Dev. & 61.66 & 14.05 & 9.08 & 0.43 & 785.42 & 560.21 & 36.44 & 5113.12 & 185.62 \\
\hline \multirow{5}{*}{ Deakin University } & Mean & 307.79 & 101.64 & 74.54 & 7.02 & 4551.67 & 2431.89 & 84.44 & 11774.11 & 777.63 \\
\hline & Median & 309.88 & 102.23 & 71.55 & 7.42 & 4498.00 & 2536.00 & 93.00 & 13274.10 & 762.21 \\
\hline & Maximum & 381.38 & 116.20 & 87.52 & 7.80 & 5106.00 & 3057.00 & 101.00 & 17460.92 & 1117.80 \\
\hline & Minimum & 221.84 & 83.63 & 63.31 & 4.64 & 4124.00 & 1456.00 & 54.00 & 4331.66 & 477.36 \\
\hline & Std. Dev. & 56.65 & 11.26 & 9.01 & 0.97 & 360.18 & 582.09 & 16.74 & 4550.77 & 229.82 \\
\hline \multirow{5}{*}{$\begin{array}{l}\text { Edith Cowan } \\
\text { University }\end{array}$} & Mean & 188.48 & 116.02 & 60.40 & 4.70 & 3378.89 & 1486.11 & 49.78 & 3136.73 & 504.05 \\
\hline & Median & 180.83 & 114.48 & 58.27 & 4.52 & 3384.00 & 1529.00 & 37.00 & 2702.71 & 515.96 \\
\hline & Maximum & 239.56 & 148.90 & 75.65 & 5.67 & 3908.00 & 2145.00 & 148.00 & 5082.99 & 554.01 \\
\hline & Minimum & 145.40 & 92.60 & 46.77 & 3.76 & 2829.00 & 1024.00 & 16.00 & 1613.85 & 354.60 \\
\hline & Std. Dev. & 32.09 & 18.31 & 9.66 & 0.58 & 424.68 & 413.24 & 41.62 & 1289.03 & 60.29 \\
\hline \multirow{5}{*}{$\begin{array}{l}\text { Flinders } \\
\text { University }\end{array}$} & Mean & 175.91 & 101.18 & 62.55 & 6.43 & 2296.89 & 929.44 & 84.00 & 18990.25 & 680.41 \\
\hline & Median & 161.46 & 97.15 & 58.42 & 5.83 & 2255.00 & 1014.00 & 84.00 & 18611.23 & 640.39 \\
\hline & Maximum & 225.01 & 125.46 & 75.36 & 9.88 & 2546.00 & 1312.00 & 110.00 & 25401.39 & 922.55 \\
\hline & Minimum & 144.17 & 79.49 & 56.39 & 5.39 & 2087.00 & 430.00 & 52.00 & 15591.13 & 547.06 \\
\hline & Std. Dev. & 32.45 & 17.01 & 7.09 & 1.41 & 179.14 & 335.75 & 17.38 & 3113.92 & 122.05 \\
\hline \multirow{5}{*}{ Griffith University } & Mean & 332.76 & 103.92 & 62.42 & 6.42 & 4580.56 & 1892.89 & 110.56 & 20564.03 & 921.95 \\
\hline & Median & 326.48 & 98.13 & 59.43 & 6.60 & 4375.00 & 1795.00 & 107.00 & 20884.91 & 841.83 \\
\hline & Maximum & 453.17 & 127.46 & 72.24 & 7.22 & 5400.00 & 2874.00 & 154.00 & 26591.78 & 1268.63 \\
\hline & Minimum & 237.79 & 87.85 & 55.48 & 5.55 & 3924.00 & 1124.00 & 73.00 & 13802.25 & 647.12 \\
\hline & Std. Dev. & 71.05 & 12.59 & 6.33 & 0.56 & 509.46 & 658.54 & 31.40 & 4170.96 & 242.17 \\
\hline \multirow{5}{*}{$\begin{array}{l}\text { James Cook } \\
\text { University }\end{array}$} & Mean & 165.41 & 96.62 & 62.53 & 7.26 & 1600.56 & 467.33 & 72.78 & 8916.42 & 441.21 \\
\hline & Median & 159.66 & 93.19 & 60.30 & 7.30 & 1621.00 & 345.00 & 71.00 & 8248.80 & 381.78 \\
\hline & Maximum & 220.92 & 112.84 & 71.11 & 9.22 & 2114.00 & 1021.00 & 88.00 & 13064.55 & 686.50 \\
\hline & Minimum & 118.92 & 77.27 & 57.59 & 5.93 & 1239.00 & 268.00 & 58.00 & 6844.20 & 293.78 \\
\hline & Std. Dev. & 38.09 & 12.74 & 5.04 & 1.16 & 300.31 & 249.23 & 9.59 & 1949.21 & 145.97 \\
\hline
\end{tabular}




\begin{tabular}{|c|c|c|c|c|c|c|c|c|c|c|}
\hline University & Statistic & $\begin{array}{l}\text { Total } \\
\text { costs }\end{array}$ & $\begin{array}{l}\text { Price of } \\
\text { academic } \\
\text { labour }\end{array}$ & $\begin{array}{l}\text { Price of non- } \\
\text { academic } \\
\text { labour }\end{array}$ & $\begin{array}{l}\text { Price of } \\
\text { capital }\end{array}$ & $\begin{array}{l}\text { Undergraduate } \\
\text { completions }\end{array}$ & $\begin{array}{l}\text { Postgraduate } \\
\text { completions }\end{array}$ & $\begin{array}{c}\text { PhD } \\
\text { completions }\end{array}$ & $\begin{array}{c}\text { National } \\
\text { competitive } \\
\text { and industry } \\
\text { grants }\end{array}$ & Publications \\
\hline \multirow{5}{*}{$\begin{array}{l}\text { La Trobe } \\
\text { University }\end{array}$} & Mean & 299.35 & 98.96 & 70.47 & 6.08 & 4346.67 & 2223.67 & 142.56 & 15539.97 & 898.41 \\
\hline & Median & 297.63 & 99.86 & 69.24 & 6.28 & 4255.00 & 2037.00 & 144.00 & 14427.55 & 890.46 \\
\hline & Maximum & 392.79 & 130.72 & 83.72 & 7.03 & 4807.00 & 2962.00 & 171.00 & 18193.45 & 1156.92 \\
\hline & Minimum & 184.58 & 39.97 & 61.84 & 4.27 & 3900.00 & 1556.00 & 113.00 & 13547.13 & 707.61 \\
\hline & Std. Dev. & 61.39 & 24.65 & 6.52 & 0.94 & 307.03 & 605.99 & 16.13 & 1849.84 & 175.84 \\
\hline \multirow{5}{*}{$\begin{array}{l}\text { Macquarie } \\
\text { University }\end{array}$} & Mean & 259.23 & 107.70 & 81.71 & 6.54 & 3095.78 & 3053.78 & 102.00 & 16759.41 & 858.81 \\
\hline & Median & 248.09 & 99.96 & 76.37 & 7.15 & 2828.00 & 3412.00 & 101.00 & 16518.22 & 730.23 \\
\hline & Maximum & 381.00 & 136.03 & 106.95 & 8.43 & 4099.00 & 3805.00 & 122.00 & 23417.83 & 1420.10 \\
\hline & Minimum & 177.55 & 92.30 & 64.72 & 4.53 & 2298.00 & 1888.00 & 88.00 & 12633.70 & 605.85 \\
\hline & Std. Dev. & 75.92 & 15.76 & 16.10 & 1.60 & 637.86 & 732.12 & 10.45 & 3748.32 & 285.41 \\
\hline \multirow{5}{*}{$\begin{array}{l}\text { Monash } \\
\text { University }\end{array}$} & Mean & 707.25 & 97.04 & 70.79 & 8.21 & 8454.11 & 3893.44 & 309.22 & 79652.66 & 2485.80 \\
\hline & Median & 690.36 & 93.72 & 67.21 & 8.26 & 9128.00 & 3714.00 & 324.00 & 71338.11 & 2360.01 \\
\hline & Maximum & 1007.67 & 119.91 & 86.83 & 10.60 & 10107.00 & 5634.00 & 384.00 & 133266.20 & 3457.74 \\
\hline & Minimum & 510.15 & 82.77 & 58.41 & 6.61 & 6374.00 & 2261.00 & 254.00 & 47277.45 & 1882.52 \\
\hline & Std. Dev. & 162.40 & 12.14 & 8.67 & 1.24 & 1392.53 & 1205.78 & 47.34 & 30040.33 & 623.06 \\
\hline \multirow{5}{*}{$\begin{array}{l}\text { Murdoch } \\
\text { University }\end{array}$} & Mean & 155.19 & 99.26 & 72.04 & 6.87 & 2011.11 & 636.67 & 79.78 & 15508.02 & 448.54 \\
\hline & Median & 154.46 & 101.31 & 73.81 & 7.08 & 2065.00 & 660.00 & 85.00 & 14748.82 & 466.99 \\
\hline & Maximum & 202.89 & 122.15 & 79.17 & 8.62 & 2101.00 & 826.00 & 92.00 & 25010.40 & 504.62 \\
\hline & Minimum & 114.07 & 76.75 & 65.03 & 4.88 & 1773.00 & 422.00 & 60.00 & 9565.80 & 383.38 \\
\hline & Std. Dev. & 29.91 & 15.28 & 4.51 & 1.49 & 110.59 & 132.21 & 10.91 & 4994.83 & 49.13 \\
\hline \multirow{5}{*}{$\begin{array}{l}\text { Queensland } \\
\text { University of } \\
\text { Technology }\end{array}$} & Mean & 359.89 & 101.85 & 65.16 & 5.64 & 6006.22 & 2684.33 & 108.89 & 15109.50 & 996.48 \\
\hline & Median & 334.58 & 101.30 & 64.00 & 5.98 & 5977.00 & 2743.00 & 100.00 & 12631.51 & 889.79 \\
\hline & Maximum & 483.06 & 121.08 & 77.57 & 7.20 & 6831.00 & 3225.00 & 151.00 & 25377.11 & 1430.18 \\
\hline & Minimum & 267.04 & 83.27 & 53.01 & 3.98 & 5258.00 & 2199.00 & 77.00 & 8417.46 & 689.49 \\
\hline & Std. Dev. & 71.82 & 12.69 & 8.58 & 0.94 & 650.73 & 320.80 & 25.27 & 6187.42 & 254.07 \\
\hline \multirow{5}{*}{$\begin{array}{l}\text { Royal Melbourne } \\
\text { Institute of } \\
\text { Technology }\end{array}$} & Mean & 404.46 & 146.85 & 80.94 & 5.64 & 5168.33 & 1974.00 & 119.00 & 10390.98 & 783.47 \\
\hline & Median & 477.97 & 163.46 & 85.90 & 5.98 & 5063.00 & 1840.00 & 110.00 & 10365.74 & 712.18 \\
\hline & Maximum & 501.80 & 184.93 & 99.42 & 7.17 & 5786.00 & 2584.00 & 180.00 & 12870.46 & 1204.90 \\
\hline & Minimum & 253.00 & 80.94 & 64.65 & 4.33 & 4651.00 & 1512.00 & 70.00 & 7273.41 & 441.74 \\
\hline & Std. Dev. & 102.48 & 36.79 & 12.70 & 1.05 & 354.87 & 367.97 & 35.02 & 1757.50 & 319.63 \\
\hline
\end{tabular}




\begin{tabular}{|c|c|c|c|c|c|c|c|c|c|c|}
\hline University & Statistic & $\begin{array}{l}\text { Total } \\
\text { costs }\end{array}$ & $\begin{array}{c}\text { Price of } \\
\text { academic } \\
\text { labour }\end{array}$ & $\begin{array}{c}\text { Price of non- } \\
\text { academic } \\
\text { labour }\end{array}$ & $\begin{array}{c}\text { Price of } \\
\text { capital }\end{array}$ & $\begin{array}{c}\text { Undergraduate } \\
\text { completions }\end{array}$ & $\begin{array}{l}\text { Postgraduate } \\
\text { completions }\end{array}$ & $\begin{array}{c}\text { PhD } \\
\text { completions }\end{array}$ & $\begin{array}{c}\text { National } \\
\text { competitive } \\
\text { and industry } \\
\text { grants }\end{array}$ & Publications \\
\hline \multirow{5}{*}{$\begin{array}{l}\text { Southern Cross } \\
\text { University }\end{array}$} & Mean & 88.84 & 104.62 & 67.09 & 5.07 & 1656.78 & 652.33 & 41.56 & 3428.10 & 164.70 \\
\hline & Median & 84.73 & 102.60 & 69.86 & 5.19 & 1820.00 & 697.00 & 34.00 & 3814.60 & 176.32 \\
\hline & Maximum & 113.71 & 120.49 & 77.67 & 5.59 & 2083.00 & 883.00 & 67.00 & 4315.69 & 219.97 \\
\hline & Minimum & 67.54 & 85.64 & 51.92 & 4.43 & 1140.00 & 324.00 & 19.00 & 2418.45 & 95.87 \\
\hline & Std. Dev. & 16.19 & 13.24 & 9.19 & 0.37 & 333.13 & 190.23 & 18.41 & 692.24 & 43.71 \\
\hline \multirow{5}{*}{$\begin{array}{l}\text { Swinburne } \\
\text { University of } \\
\text { Technology }\end{array}$} & Mean & 192.25 & 161.83 & 115.49 & 6.72 & 1875.00 & 938.11 & 46.56 & 5674.23 & 348.48 \\
\hline & Median & 224.55 & 198.94 & 133.11 & 7.59 & 1906.00 & 979.00 & 47.00 & 5599.16 & 371.93 \\
\hline & Maximum & 291.79 & 216.91 & 157.22 & 9.92 & 2519.00 & 1120.00 & 84.00 & 7944.47 & 533.13 \\
\hline & Minimum & 103.22 & 105.39 & 66.04 & 3.79 & 1543.00 & 695.00 & 23.00 & 3580.09 & 169.11 \\
\hline & Std. Dev. & 77.02 & 51.69 & 36.49 & 2.60 & 294.01 & 155.24 & 21.03 & 1405.99 & 129.11 \\
\hline \multirow{5}{*}{$\begin{array}{l}\text { University of } \\
\text { Adelaide }\end{array}$} & Mean & 330.13 & 106.72 & 70.14 & 10.96 & 2808.11 & 1048.00 & 185.11 & 58328.15 & 1366.30 \\
\hline & Median & 312.31 & 107.94 & 71.67 & 11.15 & 2850.00 & 1078.00 & 180.00 & 61956.23 & 1363.71 \\
\hline & Maximum & 438.26 & 128.08 & 82.57 & 12.69 & 3366.00 & 1932.00 & 231.00 & 75053.94 & 1674.06 \\
\hline & Minimum & 268.54 & 87.89 & 60.99 & 9.57 & 2310.00 & 484.00 & 140.00 & 39108.77 & 1136.35 \\
\hline & Std. Dev. & 60.15 & 14.35 & 7.80 & 0.98 & 377.43 & 511.12 & 29.79 & 12530.04 & 188.29 \\
\hline \multirow{5}{*}{$\begin{array}{l}\text { University of } \\
\text { Ballarat }\end{array}$} & Mean & 88.13 & 175.31 & 84.26 & 5.89 & 1065.56 & 723.67 & 12.00 & 1786.84 & 541.16 \\
\hline & Median & 96.07 & 223.58 & 97.18 & 5.90 & 1068.00 & 513.00 & 11.00 & 1960.25 & 130.39 \\
\hline & Maximum & 159.04 & 235.04 & 117.67 & 9.48 & 1320.00 & 1823.00 & 20.00 & 2679.21 & 3877.98 \\
\hline & Minimum & 45.29 & 90.03 & 52.18 & 4.40 & 762.00 & 280.00 & 3.00 & 769.90 & 65.90 \\
\hline & Std. Dev. & 39.74 & 63.22 & 25.71 & 1.58 & 177.05 & 529.51 & 7.05 & 680.00 & 1252.24 \\
\hline \multirow{5}{*}{$\begin{array}{l}\text { University of } \\
\text { Canberra }\end{array}$} & Mean & 108.49 & 117.42 & 70.38 & 4.98 & 1737.00 & 1163.44 & 18.67 & 3055.11 & 237.24 \\
\hline & Median & 101.14 & 108.28 & 70.34 & 5.04 & 1686.00 & 1118.00 & 18.00 & 2837.02 & 222.05 \\
\hline & Maximum & 150.05 & 218.41 & 83.54 & 6.10 & 2027.00 & 1490.00 & 35.00 & 4292.16 & 355.97 \\
\hline & Minimum & 85.03 & 90.54 & 52.80 & 3.97 & 1431.00 & 872.00 & 9.00 & 2017.34 & 170.04 \\
\hline & Std. Dev. & 20.90 & 39.21 & 10.00 & 0.67 & 217.67 & 198.10 & 8.26 & 782.13 & 59.70 \\
\hline \multirow{5}{*}{$\begin{array}{l}\text { University of } \\
\text { Melbourne }\end{array}$} & Mean & 783.28 & 106.65 & 64.72 & 11.31 & 7242.11 & 3693.78 & 444.00 & 137236.20 & 2567.90 \\
\hline & Median & 767.41 & 104.45 & 62.49 & 11.65 & 7174.00 & 3621.00 & 459.00 & 130198.60 & 2791.30 \\
\hline & Maximum & 1095.68 & 121.81 & 79.44 & 15.48 & 8186.00 & 4967.00 & 553.00 & 210064.20 & 3808.68 \\
\hline & Minimum & 547.42 & 88.83 & 50.95 & 8.18 & 5833.00 & 2560.00 & 303.00 & 81216.38 & 222.96 \\
\hline & Std. Dev. & 205.97 & 11.27 & 9.54 & 2.91 & 820.71 & 952.94 & 90.95 & 46704.79 & 993.30 \\
\hline
\end{tabular}




\begin{tabular}{|c|c|c|c|c|c|c|c|c|c|c|}
\hline University & Statistic & $\begin{array}{l}\text { Total } \\
\text { costs }\end{array}$ & $\begin{array}{c}\text { Price of } \\
\text { academic } \\
\text { labour }\end{array}$ & $\begin{array}{l}\text { Price of non- } \\
\text { academic } \\
\text { labour }\end{array}$ & $\begin{array}{l}\text { Price of } \\
\text { capital }\end{array}$ & $\begin{array}{l}\text { Undergraduate } \\
\text { completions }\end{array}$ & $\begin{array}{l}\text { Postgraduate } \\
\text { completions }\end{array}$ & $\begin{array}{c}\text { PhD } \\
\text { completions }\end{array}$ & $\begin{array}{c}\text { National } \\
\text { competitive } \\
\text { and industry } \\
\text { grants }\end{array}$ & Publications \\
\hline \multirow{5}{*}{$\begin{array}{l}\text { University of New } \\
\text { England }\end{array}$} & Mean & 148.74 & 94.80 & 59.60 & 6.67 & 1906.56 & 1271.67 & 77.33 & 8041.49 & 505.35 \\
\hline & Median & 138.58 & 93.70 & 56.22 & 6.49 & 1854.00 & 1309.00 & 74.00 & 8470.39 & 499.03 \\
\hline & Maximum & 175.50 & 114.59 & 71.56 & 7.96 & 2272.00 & 1553.00 & 92.00 & 9412.18 & 798.73 \\
\hline & Minimum & 126.52 & 78.30 & 52.66 & 5.28 & 1601.00 & 921.00 & 65.00 & 6375.55 & 209.54 \\
\hline & Std. Dev. & 19.94 & 12.07 & 6.98 & 0.85 & 215.11 & 241.16 & 10.27 & 1026.93 & 191.81 \\
\hline \multirow{5}{*}{$\begin{array}{l}\text { University of New } \\
\text { South Wales }\end{array}$} & Mean & 663.54 & 105.42 & 86.05 & 10.45 & 4370.44 & 3964.67 & 337.78 & 90723.41 & 2405.62 \\
\hline & Median & 637.80 & 99.97 & 89.20 & 9.70 & 4232.00 & 4242.00 & 295.00 & 86301.62 & 2294.81 \\
\hline & Maximum & 813.43 & 124.99 & 114.14 & 12.35 & 4996.00 & 4861.00 & 511.00 & 110989.10 & 3325.16 \\
\hline & Minimum & 524.45 & 82.26 & 67.06 & 8.84 & 3795.00 & 2898.00 & 250.00 & 75608.17 & 1973.05 \\
\hline & Std. Dev. & 111.23 & 15.03 & 13.51 & 1.36 & 426.82 & 729.09 & 93.23 & 13233.79 & 480.76 \\
\hline \multirow{5}{*}{$\begin{array}{l}\text { University of } \\
\text { Newcastle }\end{array}$} & Mean & 264.36 & 105.04 & 62.25 & 6.69 & 3253.67 & 1324.22 & 102.33 & 27177.50 & 868.01 \\
\hline & Median & 251.70 & 102.41 & 59.15 & 6.30 & 3221.00 & 1244.00 & 104.00 & 23198.37 & 855.64 \\
\hline & Maximum & 337.02 & 128.18 & 78.41 & 8.39 & 3547.00 & 2123.00 & 210.00 & 43500.93 & 1094.09 \\
\hline & Minimum & 201.07 & 85.84 & 51.39 & 5.51 & 2975.00 & 749.00 & 39.00 & 17227.28 & 662.46 \\
\hline & Std. Dev. & 52.21 & 15.15 & 9.77 & 1.00 & 249.42 & 482.74 & 48.91 & 10071.04 & 146.65 \\
\hline \multirow{5}{*}{$\begin{array}{l}\text { University of } \\
\text { Queensland }\end{array}$} & Mean & 670.52 & 97.96 & 62.51 & 10.79 & 5581.89 & 2138.89 & 380.33 & 106330.70 & 2712.41 \\
\hline & Median & 700.52 & 91.13 & 60.24 & 10.90 & 5759.00 & 2022.00 & 381.00 & 101650.10 & 2573.99 \\
\hline & Maximum & 895.56 & 127.22 & 75.23 & 13.18 & 5971.00 & 3077.00 & 463.00 & 146178.20 & 3483.23 \\
\hline & Minimum & 468.66 & 81.49 & 52.68 & 7.78 & 4746.00 & 1364.00 & 316.00 & 73731.94 & 2229.40 \\
\hline & Std. Dev. & 139.80 & 15.34 & 7.68 & 1.74 & 429.17 & 725.87 & 56.10 & 24517.62 & 486.87 \\
\hline \multirow{5}{*}{$\begin{array}{l}\text { University of } \\
\text { South Australia }\end{array}$} & Mean & 280.45 & 125.06 & 66.56 & 4.82 & 4596.67 & 2258.78 & 116.44 & 13719.91 & 715.46 \\
\hline & Median & 263.80 & 125.32 & 62.49 & 4.65 & 4484.00 & 1989.00 & 108.00 & 12283.40 & 694.66 \\
\hline & Maximum & 354.84 & 134.91 & 82.07 & 5.73 & 5317.00 & 3087.00 & 196.00 & 19095.63 & 1084.28 \\
\hline & Minimum & 232.69 & 115.36 & 55.72 & 4.36 & 3900.00 & 1447.00 & 47.00 & 10765.81 & 447.28 \\
\hline & Std. Dev. & 40.64 & 6.20 & 9.04 & 0.45 & 553.17 & 634.71 & 55.22 & 2958.55 & 206.65 \\
\hline \multirow{5}{*}{$\begin{array}{l}\text { University of } \\
\text { Southern } \\
\text { Queensland }\end{array}$} & Mean & 120.18 & 87.05 & 57.32 & 4.27 & 2170.44 & 1444.89 & 21.33 & 2391.49 & 202.96 \\
\hline & Median & 118.10 & 82.01 & 55.71 & 4.15 & 2138.00 & 1483.00 & 22.00 & 2432.31 & 160.68 \\
\hline & Maximum & 155.00 & 106.71 & 66.08 & 4.82 & 2361.00 & 2196.00 & 31.00 & 3436.72 & 344.87 \\
\hline & Minimum & 99.38 & 77.51 & 51.84 & 3.97 & 2014.00 & 773.00 & 11.00 & 1654.35 & 135.18 \\
\hline & Std. Dev. & 18.26 & 9.89 & 4.42 & 0.33 & 121.31 & 523.60 & 6.28 & 572.19 & 79.75 \\
\hline
\end{tabular}




\begin{tabular}{|c|c|c|c|c|c|c|c|c|c|c|}
\hline University & Statistic & $\begin{array}{l}\text { Total } \\
\text { costs }\end{array}$ & $\begin{array}{c}\text { Price of } \\
\text { academic } \\
\text { labour }\end{array}$ & $\begin{array}{l}\text { Price of non- } \\
\text { academic } \\
\text { labour }\end{array}$ & $\begin{array}{l}\text { Price of } \\
\text { capital }\end{array}$ & $\begin{array}{l}\text { Undergraduate } \\
\text { completions }\end{array}$ & $\begin{array}{l}\text { Postgraduate } \\
\text { completions }\end{array}$ & $\begin{array}{c}\text { PhD } \\
\text { completions }\end{array}$ & $\begin{array}{c}\text { National } \\
\text { competitive } \\
\text { and industry } \\
\text { grants }\end{array}$ & Publications \\
\hline \multirow{5}{*}{$\begin{array}{l}\text { University of } \\
\text { Sydney }\end{array}$} & Mean & 752.27 & 108.98 & 72.98 & 9.44 & 6611.33 & 3127.44 & 411.00 & 125695.30 & 2762.45 \\
\hline & Median & 712.48 & 103.61 & 68.93 & 9.33 & 6324.00 & 2130.00 & 393.00 & 129676.50 & 2573.86 \\
\hline & Maximum & 1017.08 & 133.07 & 93.62 & 12.09 & 8075.00 & 4992.00 & 508.00 & 179731.70 & 3852.00 \\
\hline & Minimum & 556.04 & 84.50 & 57.09 & 7.70 & 5506.00 & 1987.00 & 330.00 & 82788.34 & 1856.12 \\
\hline & Std. Dev. & 156.49 & 16.88 & 11.97 & 1.28 & 984.05 & 1377.43 & 63.96 & 35156.29 & 715.93 \\
\hline \multirow{5}{*}{$\begin{array}{l}\text { University of } \\
\text { Tasmania }\end{array}$} & Mean & 207.33 & 103.68 & 63.40 & 7.69 & 2643.22 & 470.00 & 105.67 & 21082.42 & 672.95 \\
\hline & Median & 193.33 & 100.14 & 63.81 & 7.90 & 2569.00 & 411.00 & 102.00 & 19124.12 & 646.28 \\
\hline & Maximum & 269.79 & 177.36 & 74.40 & 8.86 & 3238.00 & 753.00 & 128.00 & 31430.36 & 784.14 \\
\hline & Minimum & 145.62 & 73.44 & 49.58 & 5.68 & 2349.00 & 313.00 & 90.00 & 13481.34 & 553.09 \\
\hline & Std. Dev. & 45.91 & 30.60 & 7.15 & 1.11 & 254.74 & 147.68 & 15.00 & 6437.71 & 78.83 \\
\hline \multirow{5}{*}{$\begin{array}{l}\text { University of } \\
\text { Technology, } \\
\text { Sydney }\end{array}$} & Mean & 279.75 & 117.37 & 79.43 & 5.09 & 4174.44 & 3775.22 & 75.44 & 11514.22 & 695.67 \\
\hline & Median & 258.58 & 115.49 & 77.38 & 4.88 & 3817.00 & 3392.00 & 76.00 & 11182.97 & 593.38 \\
\hline & Maximum & 369.81 & 141.35 & 93.08 & 6.14 & 5353.00 & 5080.00 & 115.00 & 17146.31 & 1087.37 \\
\hline & Minimum & 204.48 & 93.13 & 69.15 & 3.71 & 3559.00 & 2504.00 & 52.00 & 7442.46 & 432.88 \\
\hline & Std. Dev. & 63.65 & 16.97 & 8.33 & 0.90 & 668.82 & 864.66 & 20.71 & 3593.66 & 255.05 \\
\hline \multirow{5}{*}{$\begin{array}{l}\text { University of } \\
\text { Western Australia }\end{array}$} & Mean & 378.12 & 109.15 & 68.06 & 11.81 & 2757.89 & 1015.67 & 187.78 & 65653.55 & 1476.47 \\
\hline & Median & 349.59 & 101.15 & 66.23 & 11.74 & 2752.00 & 1019.00 & 183.00 & 58843.92 & 1449.06 \\
\hline & Maximum & 535.59 & 139.16 & 80.98 & 15.55 & 3004.00 & 1421.00 & 270.00 & 92955.01 & 1715.74 \\
\hline & Minimum & 276.44 & 85.31 & 56.85 & 9.37 & 2552.00 & 708.00 & 95.00 & 45769.55 & 1296.06 \\
\hline & Std. Dev. & 88.41 & 18.19 & 7.93 & 2.12 & 150.63 & 255.74 & 49.23 & 17514.86 & 143.96 \\
\hline \multirow{5}{*}{$\begin{array}{l}\text { University of } \\
\text { Western Sydney }\end{array}$} & Mean & 293.24 & 109.49 & 75.52 & 4.54 & 5812.33 & 2345.11 & 69.56 & 6653.24 & 698.13 \\
\hline & Median & 287.66 & 107.15 & 76.65 & 4.42 & 5783.00 & 2250.00 & 71.00 & 6571.74 & 669.18 \\
\hline & Maximum & 341.17 & 130.50 & 91.40 & 5.56 & 6814.00 & 2722.00 & 94.00 & 8021.56 & 1073.78 \\
\hline & Minimum & 245.86 & 88.18 & 58.96 & 3.91 & 4736.00 & 2000.00 & 38.00 & 5770.41 & 439.19 \\
\hline & Std. Dev. & 35.30 & 16.03 & 11.54 & 0.57 & 714.87 & 252.11 & 21.26 & 774.61 & 242.24 \\
\hline \multirow{5}{*}{$\begin{array}{l}\text { University of } \\
\text { Wollongong }\end{array}$} & Mean & 207.48 & 102.40 & 72.21 & 6.98 & 2369.44 & 1820.22 & 98.11 & 16944.93 & 798.15 \\
\hline & Median & 197.35 & 101.08 & 70.82 & 7.08 & 2265.00 & 1694.00 & 102.00 & 14907.71 & 715.55 \\
\hline & Maximum & 274.29 & 116.07 & 85.06 & 8.07 & 3059.00 & 2793.00 & 138.00 & 24245.12 & 1216.91 \\
\hline & Minimum & 165.17 & 91.82 & 61.24 & 5.39 & 2017.00 & 1136.00 & 52.00 & 13773.70 & 524.50 \\
\hline & Std. Dev. & 41.97 & 8.43 & 7.90 & 0.78 & 386.59 & 600.30 & 22.93 & 3774.68 & 269.82 \\
\hline
\end{tabular}




\begin{tabular}{|c|c|c|c|c|c|c|c|c|c|c|}
\hline University & Statistic & $\begin{array}{l}\text { Total } \\
\text { costs }\end{array}$ & $\begin{array}{l}\text { Price of } \\
\text { academic } \\
\text { labour }\end{array}$ & $\begin{array}{l}\text { Price of non- } \\
\text { academic } \\
\text { labour }\end{array}$ & $\begin{array}{l}\text { Price of } \\
\text { capital }\end{array}$ & $\begin{array}{c}\text { Undergraduate } \\
\text { completions }\end{array}$ & $\begin{array}{l}\text { Postgraduate } \\
\text { completions }\end{array}$ & $\begin{array}{c}\text { PhD } \\
\text { completions }\end{array}$ & $\begin{array}{c}\text { National } \\
\text { competitive } \\
\text { and industry } \\
\text { grants }\end{array}$ & Publications \\
\hline \multirow{5}{*}{$\begin{array}{l}\text { Victoria } \\
\text { University of } \\
\text { Technology }\end{array}$} & Mean & 228.64 & 155.36 & 86.45 & 6.22 & 2754.67 & 1560.89 & 46.22 & 4457.89 & 447.77 \\
\hline & Median & 249.29 & 182.44 & 94.27 & 6.75 & 2667.00 & 1436.00 & 47.00 & 4693.08 & 474.01 \\
\hline & Maximum & 315.91 & 214.81 & 113.73 & 7.61 & 3202.00 & 2091.00 & 78.00 & 5383.47 & 627.84 \\
\hline & Minimum & 148.87 & 94.27 & 56.60 & 4.55 & 2503.00 & 1210.00 & 18.00 & 2436.69 & 241.99 \\
\hline & Std. Dev. & 70.88 & 51.07 & 24.52 & 1.31 & 251.99 & 306.26 & 20.73 & 844.40 & 135.68 \\
\hline
\end{tabular}

Notes: (i) Full-time equivalent academic and non-academic staff: DEST, Higher Education Statistics Collections (Various Issues), Canberra (www.dest.gov.au - accessed May 2008); (ii) expenditure on non-labour inputs: DEST, Finance - Selected Higher Education Statistics (Various Issues), Canberra (www.dest.gov.au - accessed May 2008), non-labour inputs consist of non-labour academic and research expenditure (equipment, travel, consumables, etc.), libraries, other academic support services, student services, public services, buildings and grounds and administration and other general institution services; (iii) actual student load (EFTSU) all undergraduate and postgraduate students: DEST, Higher Education Statistics Collections (Various Issues), Canberra (www.dest.gov.au - accessed May 2008); (iv) undergraduate, postgraduate and PhD completions: DEST, Students - Selected Higher Education Statistics (Various Issues), Canberra (www.dest.gov.au - accessed May 2008), postgraduate completions consist of Master's by research, by coursework and other postgraduates excludes PhD completions. A PhD completion includes both research and coursework components; (v) for national competitive grants and industry grants: DEST, Higher Education Research Data Collection time series data 1992-2006 (via www.avcc.edu.au - accessed May 2008); (vi) weighted publications: AVCC, Higher Education Research Data Collection time series data 1992-2006 (www.avcc.edu.au - accessed May 2008); (vii) total costs are in \$ millions, prices and grants are in \$ thousands, other outputs in values. 
Table 2 Estimated cost function

\begin{tabular}{|c|c|c|c|c|c|c|c|}
\hline & Coefficient & Std. error & $\mathrm{p}$-value & & Coefficient & Std. error & p-value \\
\hline$\beta_{0}$ & -38.2664 & 12.3717 & 0.0020 & $\gamma_{25}$ & $-3.20 \mathrm{E}-05$ & $1.02 \mathrm{E}-04$ & 0.7548 \\
\hline$\beta_{1}$ & 0.0831 & 0.1515 & 0.5835 & $\gamma_{26}$ & 0.0018 & 0.0022 & 0.4043 \\
\hline$\beta_{2}$ & 2448 & 0.2775 & 0.3780 & $\gamma_{27}$ & $1.74 \mathrm{E}-06$ & 6.19E-06 & 0.7788 \\
\hline$\beta_{3}$ & 5721 & - & - & $\gamma_{28}$ & $1.54 \mathrm{E}-05$ & 0.0002 & .9422 \\
\hline$\beta_{4}$ & 0.0287 & 0.0077 & 0.0002 & $\gamma_{34}$ & 0.0041 & 0.0009 & 0.0001 \\
\hline$\beta_{5}$ & 441 & 0.0124 & 0.0004 & $\gamma_{35}$ & -0.0010 & 0.0014 & 0.4778 \\
\hline$\beta_{6}$ & 3934 & 0.2277 & 0.0845 & $\gamma_{36}$ & & 0.0181 & 0.0118 \\
\hline$\beta_{7}$ & 0055 & 0007 & 0.0001 & $\gamma_{37}$ & -0.0 & 0.0001 & 0.0001 \\
\hline$\beta_{8}$ & -0.1939 & 0.0343 & 0.0001 & $\gamma_{38}$ & 0.0142 & 0.0027 & 0.0001 \\
\hline$\delta_{1}$ & 0.0009 & 0.0016 & 0.6013 & $\gamma_{45}$ & $-1.40 \mathrm{E}-05$ & 2.79E-06 & 0.0001 \\
\hline$\delta_{2}$ & 0.0116 & 0.0056 & 0.0395 & $\gamma_{46}$ & $-2.97 \mathrm{E}$ & 4.58E-05 & 0.5173 \\
\hline$\delta_{3}$ & 0.0495 & 0.2323 & 0.8311 & $\gamma_{47}$ & $-7.59 \mathrm{E}-07$ & $1.55 \mathrm{E}-07$ & 0.0001 \\
\hline$\delta_{4}$ & $-1.14 \mathrm{E}-06$ & $2.11 \mathrm{E}-06$ & 0.5883 & $\gamma_{48}$ & 3.85E-05 & 7.87E-06 & 0.0001 \\
\hline$\delta_{5}$ & $1.12 \mathrm{E}-05$ & 4.13E-06 & 0.0069 & $\gamma_{56}$ & $-4.74 \mathrm{E}-06$ & 0.0001 & 0.9492 \\
\hline$\delta_{6}$ & 0.0012 & 0.0017 & 0.4748 & $\gamma_{57}$ & $4.92 \mathrm{E}-07$ & 2.14E-07 & 0.0214 \\
\hline$\delta_{7}$ & 4.77E-08 & $1.49 \mathrm{E}-08$ & 0.0015 & $\gamma_{58}$ & 3.66E-07 & $1.08 \mathrm{E}-05$ & 0.9729 \\
\hline$\delta_{8}$ & 2.78E-05 & $9.26 \mathrm{E}-06$ & 0.0027 & $\gamma_{67}$ & 6.31E-07 & 3.47E-06 & 0.8560 \\
\hline$\gamma_{12}$ & -0.0030 & & 0.2754 & $\gamma_{68}$ & & 0.0002 & 0.6530 \\
\hline$\gamma_{13}$ & 0.0339 & 0.0128 & 0.0083 & $\gamma_{78}$ & $-1.63 \mathrm{E}-06$ & $5.50 \mathrm{E}-07$ & 0.0030 \\
\hline$\gamma_{14}$ & 0.0001 & 0.0000 & 0.0050 & \multicolumn{3}{|c|}{$\mathrm{R}^{2}$} & $\overline{0.9862}$ \\
\hline$\gamma_{1}$ & -0.0001 & 0 & 0.1963 & \multicolumn{3}{|c|}{ No input price effects } & 2.3226 \\
\hline$\gamma_{16}$ & 0.0005 & & 0.6925 & \multicolumn{3}{|c|}{ No output effects } & 343.6337 \\
\hline$\gamma_{17}$ & $-7.22 \mathrm{E}-06$ & 3.50E-06 & 0.0396 & \multicolumn{3}{|c|}{ No linear variables effects } & 345.5634 \\
\hline$\gamma_{18}$ & 0.0001 & & 0.5587 & \multicolumn{3}{|c|}{ No squared variables effects } & 34.3163 \\
\hline$\gamma_{23}$ & -0.0650 & 0.0228 & 0.0044 & \multicolumn{3}{|c|}{ No input price cross effects } & 9.9697 \\
\hline$\gamma_{24}$ & -0.0001 & 0.0001 & 0.2909 & \multicolumn{3}{|c|}{ No output cross effects } & 392.6252 \\
\hline
\end{tabular}

Notes: $\beta_{0}$ is the fixed cost term, $\beta_{i}(i=1,2, \ldots, 8)$ are the slope coefficients of the linear term, $\delta_{i}(i=$ $1,2, \ldots, 5)$ are the slope coefficients of the quadratic terms, $\gamma_{i j}(i=1,2, \ldots, 10, j=1,2, \ldots, 10$ and $i \neq$ $j$ ) are the slope coefficients of the cross-product terms, $C$ is total operating costs and $y_{1}$ to $y_{8}$ are the prices of the academic and non-academic labour inputs, capital inputs, undergraduate, postgraduate and $\mathrm{PhD}$ completions, competitive grants and publications. 
Table 3 Marginal and average incremental costs

\begin{tabular}{|c|c|c|c|c|c|c|}
\hline & & \multicolumn{5}{|c|}{ Marginal costs (MC) } \\
\hline & & $\begin{array}{l}\text { Undergraduate } \\
\text { completions }\end{array}$ & $\begin{array}{l}\text { Postgraduate } \\
\text { completions }\end{array}$ & $\begin{array}{c}\text { PhD } \\
\text { completions }\end{array}$ & $\begin{array}{l}\text { National } \\
\text { competitive and } \\
\text { industry grants }\end{array}$ & Publications \\
\hline \multirow{12}{*}{ 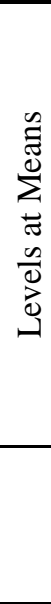 } & $50 \%$ & 49.9628 & 0.0000 & 129.8389 & 1.3981 & 13.3743 \\
\hline & $75 \%$ & 48.9436 & 4.7112 & 168.0912 & 1.4176 & 19.8917 \\
\hline & $100 \%$ & 47.9245 & 9.7948 & 206.3436 & 1.4371 & 26.4092 \\
\hline & $125 \%$ & 46.9054 & 14.8784 & 244.5959 & 1.7729 & 32.9267 \\
\hline & $150 \%$ & 45.8863 & 19.9620 & 282.8482 & 2.1087 & 39.4442 \\
\hline & $175 \%$ & 44.8671 & 25.0456 & 321.1005 & 2.4445 & 45.9617 \\
\hline & $200 \%$ & 43.8480 & 30.1292 & 359.3528 & 2.7803 & 52.4792 \\
\hline & $225 \%$ & 42.8289 & 35.2128 & 397.6051 & 3.1161 & 58.9966 \\
\hline & $250 \%$ & 41.8098 & 40.2965 & 435.8574 & 3.4519 & 65.5141 \\
\hline & $300 \%$ & 39.7715 & 50.4637 & 512.3620 & 4.1235 & 78.5491 \\
\hline & & \multicolumn{5}{|c|}{ Average incremental costs (AIC) } \\
\hline & & $\begin{array}{l}\text { Undergraduate } \\
\text { completions }\end{array}$ & $\begin{array}{l}\text { Postgraduate } \\
\text { completions }\end{array}$ & $\begin{array}{c}\mathrm{PhD} \\
\text { completions }\end{array}$ & $\begin{array}{c}\text { National } \\
\text { competitive and } \\
\text { industry grants }\end{array}$ & Publications \\
\hline \multirow{10}{*}{ 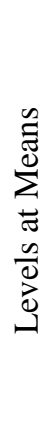 } & $50 \%$ & 50.9819 & 0.0000 & 91.5866 & 0.4296 & 6.8568 \\
\hline & $75 \%$ & 50.4723 & 0.0000 & 110.7128 & 0.5975 & 10.1155 \\
\hline & $100 \%$ & 49.9628 & 0.0000 & 129.8389 & 0.7654 & 13.3743 \\
\hline & $125 \%$ & 49.4532 & 2.1694 & 148.9651 & 0.9333 & 16.6330 \\
\hline & $150 \%$ & 48.9436 & 4.7112 & 168.0913 & 1.1013 & 19.8917 \\
\hline & $175 \%$ & 48.4341 & 7.2530 & 187.2174 & 1.2692 & 23.1505 \\
\hline & $200 \%$ & 47.9245 & 9.7948 & 206.3436 & 1.4371 & 26.4092 \\
\hline & $225 \%$ & 47.4149 & 12.3366 & 225.4697 & 1.6050 & 29.6680 \\
\hline & $250 \%$ & 46.9054 & 14.8784 & 244.5959 & 1.7729 & 32.9267 \\
\hline & $300 \%$ & 45.8863 & 19.9620 & 282.8482 & 2.1087 & 39.4442 \\
\hline
\end{tabular}


Table 4 Economies of scale and scope

\begin{tabular}{|c|c|c|c|c|c|c|c|}
\hline & & \multicolumn{6}{|c|}{ Economies of scale } \\
\hline & & $\begin{array}{l}\text { Undergraduate } \\
\text { completions }\end{array}$ & $\begin{array}{l}\text { Postgraduate } \\
\text { completions }\end{array}$ & $\begin{array}{c}\mathrm{PhD} \\
\text { completions }\end{array}$ & $\begin{array}{c}\text { National } \\
\text { competitive and } \\
\text { industry grants }\end{array}$ & Publications & RAY \\
\hline \multirow{10}{*}{ 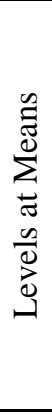 } & $50 \%$ & 1.0204 & 0.0000 & 0.7054 & 0.3073 & 0.5127 & 1.3062 \\
\hline & $75 \%$ & 1.0312 & 0.0000 & 0.6586 & 0.4215 & 0.5085 & 1.1955 \\
\hline & $100 \%$ & 1.0425 & 0.0000 & 0.6292 & 0.5327 & 0.5064 & 1.0984 \\
\hline & $125 \%$ & 1.0543 & 0.1458 & 0.6090 & 0.5265 & 0.5052 & 0.9828 \\
\hline & $150 \%$ & 1.0666 & 0.2360 & 0.5943 & 0.5223 & 0.5043 & 0.8853 \\
\hline & $175 \%$ & 1.0795 & 0.2896 & 0.5830 & 0.5192 & 0.5037 & 0.8020 \\
\hline & $200 \%$ & 1.0930 & 0.3251 & 0.5742 & 0.5169 & 0.5032 & 0.7299 \\
\hline & $225 \%$ & 1.1071 & 0.3503 & 0.5671 & 0.5151 & 0.5029 & 0.6669 \\
\hline & $250 \%$ & 1.1219 & 0.3692 & 0.5612 & 0.5136 & 0.5026 & 0.6114 \\
\hline & $300 \%$ & 1.1537 & 0.3956 & 0.5520 & 0.5114 & 0.5022 & 0.5182 \\
\hline \multicolumn{8}{|c|}{ Economies of scope } \\
\hline \multirow{11}{*}{ 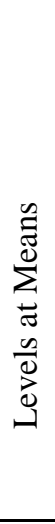 } & & $\begin{array}{l}\text { Undergraduate } \\
\text { completions }\end{array}$ & $\begin{array}{l}\text { Postgraduate } \\
\text { completions }\end{array}$ & $\begin{array}{c}\mathrm{PhD} \\
\text { completions }\end{array}$ & $\begin{array}{c}\text { National } \\
\text { competitive and } \\
\text { industry grants }\end{array}$ & Publications & GES \\
\hline & $50 \%$ & 0.0807 & 0.1037 & 0.0367 & 0.1436 & -0.1167 & 0.1243 \\
\hline & $75 \%$ & 0.1235 & 0.1587 & 0.0561 & 0.2199 & -0.1790 & 0.1898 \\
\hline & $100 \%$ & 0.1682 & 0.2163 & 0.0764 & 0.2996 & -0.2441 & 0.2584 \\
\hline & $125 \%$ & 0.2150 & 0.2765 & 0.0976 & 0.3831 & -0.3122 & 0.3302 \\
\hline & $150 \%$ & 0.2640 & 0.3396 & 0.1199 & 0.4704 & -0.3834 & 0.4054 \\
\hline & $175 \%$ & 0.3154 & 0.4057 & 0.1432 & 0.5620 & -0.4581 & 0.4842 \\
\hline & $200 \%$ & 0.3693 & 0.4750 & 0.1676 & 0.6580 & -0.5364 & 0.5669 \\
\hline & $225 \%$ & 0.4259 & 0.5478 & 0.1933 & 0.7589 & -0.6186 & 0.6537 \\
\hline & $250 \%$ & 0.4855 & 0.6244 & 0.2203 & 0.8650 & -0.7051 & 0.7451 \\
\hline & $300 \%$ & 0.6143 & 0.7901 & 0.2788 & 1.0945 & -0.8923 & 0.9427 \\
\hline
\end{tabular}


Table 5 Australian university cost efficiency index

\begin{tabular}{ll}
\hline University & Index \\
\hline University of Ballarat & 0.8758 \\
Southern Cross University & 0.8889 \\
Flinders University & 0.8977 \\
Charles Sturt University & 0.9128 \\
University of Adelaide & 0.9193 \\
University of Canberra & 0.9240 \\
University of Tasmania & 0.9327 \\
Murdoch University & 0.9380 \\
Swinburne University of Technology & 0.9519 \\
Macquarie University & 0.9524 \\
University of Melbourne & 0.9526 \\
University of South Australia & 0.9575 \\
University of Wollongong & 0.9575 \\
University of Western Sydney & 0.9681 \\
Curtin University of Technology & 0.9786 \\
University of Technology, Sydney & 0.9839 \\
University of Sydney & 0.9871 \\
Monash University & 0.9945 \\
Deakin University & 0.9974 \\
University of Newcastle & 0.9979 \\
Australian National University & 0.9983 \\
Edith Cowan University & 0.9993 \\
Australian Catholic University & 1.0034 \\
Charles Darwin University & 1.0192 \\
Victoria University of Technology & 1.0208 \\
University of Western Australia & 1.0225 \\
University of New England & 1.0238 \\
La Trobe University & 1.0278 \\
Queensland University of Technology & 1.0344 \\
University of Queensland & 1.0549 \\
Griffith University & 1.0705 \\
Central Queensland University & 1.0756 \\
University of Southern Queensland & 1.1015 \\
University of New South Wales & 1.1112 \\
Royal Melbourne Institute of Technology & 1.1249 \\
James Cook University & 1.1674 \\
\hline
\end{tabular}

